\title{
APORTACIONES AL ESTUDIO DEL GREMIO DE CUCHILLEROS
}

POR

\author{
RAFAEL MARTINEZ DEL PERAL FORTON
}

\section{INTRODUCCIÓN}

PLINIO, al comienzo del libro séptimo de su Historia Natural, refiriéndose a la naturaleza del hombre, dice: «La primacía se la daremos con justicia al hombre para quien la naturaleza parece haberlo creado todo, con alto y costoso pago, a cambio de sus muchos y grandes dones; de tal modo, que no se puede valorar bien si ha sido para él la mejor madre o una madrastra cruel. En primer lugar, a él solo de todos los seres vivos cubre con recursos ajenos; a los demás les concedió distintas protecciones: conchas, cortezas, pieles, espinas, pelos, púas, crines, plumaje, escamas, lana; incluso a los troncos de los árboles les protegió del frío y del calor con una corteza a veces doble. Solamente al hombre lo arrojó desnudo en la desnuda tierra desde el día de su nacimiento y lo entregó inmediatamente a los gemidos y al llanto, a ningún otro de los seres vivos le entrègó a las lágrimas, y éstas (se las dio al hombre) desde el comienzo de su vida» ${ }^{1}$.

Efectivamente, Dios creó al hombre con los preciados dones de la inteligencia y la libertad, pero le privó de una serie de defensas corporales imprescindibles para su propia subsistencia y desarrollo. El hombre, desde el primer momento, necesitó alimentarse, abrigarse, tener un lugar donde cobijarse, defenderse de sus enemigos, fieras y hombres, y para todo ello le era imprescindible contar con algún instrumento con el que pudiera obtener alimentos para su sustento, conseguir pieles para cubrirse, cortar materiales para construirse un hogar y luchar contra sus adversarios; este instrumento iba a ser el cuchillo.

1 «Principium jure tribuetur homini, cujus causa videtur cuncta alia genuisse natura, magna saeva mercede contra tanta sua munera: non sit ut satis aestimare parens melior homini, an tristis noverca fuerit. Ante omnia unum animantium cunctorum alienis velat opibus; ceteris varie tegumenta tribuit, testas, cortices, coria, spinas, villos, setas, pilos, plumam, pennas, squamas, vellera. Truncos etiam arboresque cortice interdum gemino, a frigoribus et calore tutata est. Hominem tantum nudum, et in nuda humo, natali die abjicit ad vagitus statim et ploratum, nullumque tot animalium aliud ad lacrimas, et has protinus vitae principio." 
El cuchillo sería primero una piedra toscamente tallada, después finamente pulida; más tarde, a base de metal, el hombre construiría un auténtico cuchillo con punta y filo agudos, que además de ser de una fabricación más fácil sería de una utilización más eficaz. Así, el cuchillo, en cualquiera de las formas y variedades que luego irá adquiriendo con el correr del tiempo (puñal, machetc, espada, daga, hacha, navaja, etc.), se convierte, nada menos y nada más, que en el instrumento más importante de la historia de la humanidad.

Esta afirmación que se acaba de hacel puede, a primera vista, parecer excesivamente rotunda, pero no lo es en absoluto. Piénsese que durante milenios el hombre precisó del cuchillo para su propio sustento, bienestar y progreso; para dar caza a los mamíferos que le servían de alimento - -y ello tenía que hacerlo cotidianamente-; para matar y descuartizar a las fieras cuyas pieles precisaba para cubrir su cuerpo durante las centenarias glaciaciones y duros inviernos; necesitó de esta arma blanca para curtir y cortar las pieles que iban a servirle también de calzado y abrigado gorro, para recortar sus elementales trajes, para seccionar las ramas de los árboles con que construir sus chozas, cabañas y refugios; para hacer la leña con que calentar su cuerpo y sus alimentos; para construirse sus herramientas de trabajo cotidiano y aparejos para poder utilizar los animales con los que iba a ayudarse en su oficio y en el transporte y acarreo; para rasurar su barba; en cirugía; para defender el territorio de la comunidad de los ataques e incursiones ajenas y para imponer la autoridad y hasta para administrar justicia.

Sólo con la utilización generalizada de la pólvora como elemento ofensivo y defensivo - que tuvo lugar en la Edad Moderna y, por tanto, es de ayer-, el descubrimiento de la electricidad, la invención del motor de explosión y alguna que otra innovación posterior, perdieron el cuchillo y sus derivados su primacía y quedaron relegados a un segundo término.

En nuestra Patria, el cuchillo es utilizado, apreciado y fabricado, hasta el punto de que algún centro de producción era ya famoso en la Antigüedad, como sucedió con Toledo, pos la calidad de sus aceros y la perfección de su elaboración. Así lo atestigua el poeta Gracio Falisco en su obra De Venatione, donde en los versos 337 a 341 dice: «Vigila tú mismo todos los trabajos. Estate presente cuando se fabriquen tus armas y tu equipo de caza. Las armas allanan las dificultades. Que tus pies sean calzados con borceguíes; que tus sirvientes sean vestidos con piel de color leonada y con gorro de tejón de pelo blanco; que ciñan las ijadas con el cuchillo toledano.... ${ }^{2}$.

${ }^{2}$ Este último verso latino dice textualmente: «Ima Toletano praecingant ilia cultro». Gratro Falisco fue un poeta, probablemente de Faleria, contemporáneo de 
El desarrollo de esta industria artesanal le valió a Toledo el que con el tiempo le fueran concedidos privilegios y exenciones para no pagar ciertos gravámenes, como las alcabalas y otros varios que recaían sobre la venta de sus armas blancas y la compra de las materias primas necesarias, como el hierro, el acero, las cuernas, el hueso, la madera, el marfil, los cueros y otros metales imprescindibles para los puños, los adornos y las vainas.

Pero esta fabricación no es exclusiva de Toledo; centros productores existen en las principales ciudades españolas, pues la demanda es ininterrumpida y creciente. Así, las Ordenanzas de Sevilla de 1632, en que se recogen todas las disposiciones reales anteriores, promulgadas para «la buena gouernacion del bien publico y pacifico Regimiento de Sevilla y su tierra», en el capítulo «De los cuchilleros», se dice: «Siendo como es dicho oficio de cuchilleria, vno de los principales oficios y arte, que ay en la dicha cibdad.»

Demostrada la importancia del cuchillo como instrumento inseparable en la vida del hombre, se tenía la intención de profundizar en una de sus variantes más ricas: la navaja, arma blanca corta que apareció en España a principios del siglo Xvil y que hasta el XIX tuvo en nuestro país especial aceptación y desarrollo no sólo entre el pueblo llano, sino en todos los estamentos sociales.

Pero la realidad histórica no ha permitido esta restringida profundización. El gremio de navajeros no existió nunca. Nunca hubo un grupo de profesionales que, dedicados a fabricar única y exclusivamente navajas, decidieran organizarse corporativamente a fin de defender mejor sus intereses, al igual que lo hacían los trabajadores especializados de otros oficios. El oficio de navajero vivió incardinado en el de cuchillero, formando parte del mismo, siguiendo sus mismos avatares y desarrollándose brillantemente, aunque sin llegar a un grado de autonomía tal que quedase desmembrado del gremio de cuchilleros y apareciese en la vida ciudadana como algo independiente.

Prueba de lo expuesto son una serie de testimonios muy significativos que se van a exponer a continuación.

José Gestoso y Pérez, que escribió Ensayo de un diccionario de los artifices que florecieron en esta ciudad de Sevilla desde el siglo XIII al $X V I I I^{3}$, recoge en sus tres tomos los nombres de ciento treinta y tres

Ovidio - por tanto, debió de vivir los años inmediatamente anteriores a la venida de Cristo-, quien le menciona en su Epístola del Ponlo Ad invidum, concretamente en el verso 34, al decir: «Aptaque venanti Gratius arma daret» (Gracio daba adecuadas armas al que caza).

"Obla publicada en Sevilla, en 1899. En el tomo I (págs. 126-136 y 391-393) cita ciento veintiocho cuchilleros, en el tomo II (págs. 361 y 392-394) menciona tres pu- 
cuchilleros, tres puñaleros y diecisiete vaineros, $y$, sin embargo, no cita a un solo navajero. ¿Por qué? Porque aunque allí se fabricaron navajas, sus artífices eran genéricamente denominados cuchilleros.

Antonio Matilla Tascón ${ }^{4}$, en su exhaustivo estudio sobre el catastro del marqués de la Ensenada, que como es sabido contempló las veintidós provincias de los reinos de Castilla y León, no menciona ni una sola vez el oficio de navajero, pese a que entre 1750 y 1756 , fechas en las que se contestó al cuestionario y se elaboró el catastro, esta industria no había desaparecido en absoluto, si bien había iniciado ya su decadencia.

El gran estudioso de la cuchillería española de otros tiempos que fue Rico y Sinobas, en su Noticia bistórica de la cucbillería y de los cuchilleros antiguos en España ${ }^{5}$, cita setenta y nueve maestros cuchilleros que fabricaban arcabuces, dagas, espadas, cuchillos, moharras, hojas de afeitar, navajas, cortaplumas, tijeras, cañivetes y jaras, vergas, dardos y lances para ballestas. La simple enumeración de estas armas es demostración del carácter extraordinariamente amplio que el oficio y gremio de cuchilleros tenía.

En el estatuto y recuento de los gremios existentes en Zaragoza en 1575 , «a fin de remediar las acusaciones que contra algunos oficios mecánicos se han intentado en la Corte del Justicia de Aragón, a instancia de cierto particular, por averse ajuntado sin asistencia del oficial real como por Fuero del presente Reino son obligados...», se recogen setenta y cinco gremios distintos, y entre los relativos al metal están los freneros, anzoleros, agujeros, espaderos, cuchilleros, puñaleros, herreros, cerrajeros, plateros, batifullas, buidores, campaneros, estañeros y doradores de fuego, sin que aparezcan los navajeros, y ello porque, además de que en esa fecha la navaja no había hecho todavía su aparición a nivel popular y general, las primeras que pudieron fabricarse fueron, lógicamente, elaboradas por los hábiles y tenaces cuchilleros aragoneses ${ }^{6}$.

Según el manuscrito Bolsa de insaculación de las distintas parroquias de Zaragoza, que se conserva en el Archivo Municipal de esta ciudad y que ha sido recogido por Redondo ${ }^{7}$, existían entre el vecindario de Zara-

ñaleros y diecisiete vaineros y en el tomo III (págs. 78-81) recoge cinco cuchilleros más. Probablemente hay que descartar algunos maestros de estas cifras debido a la repetición de los mismos en virtud de los diversos nombres por los que eran conocidos.

* Antonio Matilla Tascón, La única contribución y el calastro de Ensenada, Madrid, 1947.

5 Manufi. Rico y Sinobas, artículo publicado en el «Almanaque del Museo de la Industria», Madrid, 1871.

- Gullermo Redondo Veintemlilas, Las corporaciones de arlesanos de Zaragoza c'n cl siglo XVII, Institución Fernando el Católico, Zaragoza, 1982, págs. 82 y 85.

7 Gulllermo Redondo Veintemillas, op. cit., págs. 247-253. 
goza, hacia 1642, trescientas setenta y dos actividades distintas, que enumera, sin que aparezca entre las mismas la de los navajeros - pese a que se citan otras tan casuísticas como «beata», «ciego» o «apuntador de lancetas»-, deduciendo de ello que las navajas son fabricadas por los espaderos y puñaleros, que sí aparecen citados.

En los repartos de 1718, 1726, 1733 y 1742 efectuados en Málaga no aparece el gremio de navajeros ${ }^{8}$.

Entre los sesenta gremios identificados documentalmente en la Murcia del siglo xvin figuran los cuchilleros o «compositores» de armas blancas, según consta en la «Lista de corporaciones y gremios que han servido de base para el repartimiento de bajas en los años desde 1814 a 1817 », sin que el gremio de los navajeros se encuentre entre ellos ${ }^{9}$.

Que el gremio de navajeros no aparezca reseñado en los documentos históricos que han Ilegado hasta nosotros es, hasta cierto punto, natural y lógico, debido a que el gremio como tal no llegó a existir en la vida municipal española, pero que apenas aparezca citado el gremio de cuchilleros — profesionales dedicados a una actividad tan crucial y cuya existencia corporativa está documentalmente probada- es algo que no resulta fácil de entender y cuya etiología habría que estudiar más a fondo.

El que en su día fue jefe del Archivo de la Corona de Aragón, Manuel de Bofarull y de Sartorio, en su libro ${ }^{10}$ sobre las asociaciones profesionales del pasado, recoge ciento dieciocho gremios y cofradías, y no menciona en ningún momento el gremio de los cuchilleros. Ello es más significativo si se recuerda que en las novecientas veintiuna páginas de los dos tomos de su obra se citan corporaciones tan singulares como la Cofradía Real de Barcelona para hacer la cruzada contra los sarracenos, la Cofradía de Ciegos Mendigos de Barcelona y la de Corpore Christi, compuesta de desgraciados a quienes el rey de Castilla había mandado cortar los puños después de una guerra.

Entre los cincuenta y ocho gremios que, según Elena Amat ${ }^{11}$, existían en Madrid en 1636 figuraban los espaderos, pero no los cuchilleros, lo cual significa que la clasificación gremial de esta época y ciudad estaba incorrectamente realizada, dado que dicho gremio existía en esas fechas en la capital de España, como se verá después.

" Siro Villas Tinoco, Los gremios malagueños (1700-1746) (Tesis doctoral), Universidad de Málaga, 1982, pág. 737.

y Juan García Abellán, Organización de los gremios en la Murcia del siglo XVIII y recopilación de ordenanzas, Academia Alfonso X el Sabio, Murcia, 1976, pág. 47.

${ }^{10}$ Gremios y cofradias de la antigua Corona de Aragón, tomo I, Barcelona, 1876; tomo II, Barcelona, 1910.

"Los libreros de Madrid en el siglo XVIII, Madrid, 1931, pág. 49. 
En el catastro realizado por el marqués de la Ensenada, ya mencionado, no aparece el gremio de cuchilleros en diez de las veintidós provincias de los reinos de Castilla y León, concretamente en Avila, Burgos, Córdoba, Cuenca, Granada, Ciudad Real, Salamanca, Sevilla, Soria y Zamora, a pesar de la importancia de estas ciudades y algunas de las villas de su demarcación a mediados del siglo XviII.

En las disposiciones forales de Aragón de 1553 se contiene una relación de actividades laborales, cuarenta y una en total, y los cuchilleros siguen sin aparecer; de ello se puede deducir que, con toda probabilidad, estarían integrados en alguno de los gremios citados que parecen más afines: herreros, armeros y "otros que obran de martillo» ${ }^{12}$.

El gremio de cuchilleros tampoco se encuentra citado en los repartos malagueños de 1726 y $1733^{13}$.

Para terminar con los testimonios sobre la gran ausencia del gremio de cuchilleros en los documentos que han llegado hasta nosotros, basta recordar que cuando el oficial deseaba ascender al grado de maestro precisaba hacer la pieza o piezas de examen - lo que se llamó «obra maestra»- en las condiciones previstas por sus propias ordenanzas, y así, los espaderos de Barcelona, en 1567, debían fabricar una espada, una daga, un alfanje morisco y un cuchillo ${ }^{14}$.

En conclusión, se puede afirmar que el gremio de navajeros no existió nunca y que el de cuchilleros no disfrutó de autonomía desde el momento en que los gremios hicieron su aparición en la vida social, sino que hubo que esperar a épocas más tardías - aunque las variaciones de un lugar a otro pueden ser de siglos-, pues en los comienzos de la vida gremial vivía asociado con el de ferrería o del art de foc y después con los cerrajeros, espaderos, armeros, freneros y herreros ${ }^{15}$.

Si son siempe varias y diversas las dificultades con que toda investigación científica se tropieza a la hora de efectuar el trabajo, en el presente caso la ausencia de documentación de primera mano ha constituido el mayor obstáculo y al mismo tiempo su reto. Es realmente poquísima, como ya se ha apuntado anteriormente, la documentación que existe sobre esta materia en comparación con la que debería existir. Y no se trata

12 Guillermo Redondo Veintemillas, op. cit., pág. 56.

${ }^{13}$ Siro Villas Tinoco, op. cit., pág. 737.

"Juan Uña y Sarthou, Las asociaciones obreras en Espuña, Madrid, 1900, pág. 245.

is «Componen el gremio de armeros los siguientes brazos o ramos: espaderos y guarnecedores; doradores, plateros, estañadores de hoja, de fus de olla y pavonadores; cuchilleros, dagueros, forjadores de armas blancas y afiladores; guiraceros, guarnecedores de estuches, cajas de joyas y relojes; freneros, espoloneros y guarnecedores de armas blancas; silleros, sogueros y mancheros, y bordadores» (MAnuel Cruilles y Sngarra [Marqués de Cruilles], Los gremios de Valencia, Valencia, 1883, pág. 43). 
de una visión subjetiva y magnificada del tema, pues sobre otros gremios es abundantísimo lo que ha perdurado. Sin saber exactamente por qué, los veneros en que hay que beber a la hora de investigar sobre cuchillería antigua están prácticamente secos.

Con independencia de un estudio riguroso sobre la etiología de la ausencia de documentos históricos en los que fundamentarse, existe una serie de causas de tipo general que dificulta el hallazgo de ordenanzas y otros documentos gremiales de los cuchillcros. Entre ellos están:

En primer lugar, la decadencia progresiva de sus artes y oficios a lo largo de los tiempos. En los últimos siglos ya no se producían dagas, misericordias, ricos puñales de arzón, espadas roperas, tijeras profusamente grabadas, etc.

En segundo lugar están las guerras -internacionales o civiles-y las revoluciones, tan frecuentes por desgracia en la historia de nuestro país. Destacan por el daño causado a los archivos, bibliotecas, museos, iglesias, conventos, casas consistoriales y en general a nuestro patrimonio cultural la guerra de Sucesión (1701-1714), la guerra de la Independencia (18081814), las tres guerras carlistas (1833-1876), las revoluciones de $1854 \mathrm{y}$ 1868 y la guerra civil de 1936.

En tercer lugar es de resaltar la secular incuria española. Las autoridades gremiales, con gran frecuencia, conservaron los documentos, libros, ordenanzas, etc., en sus propias casas, y luego sus descendientes, en momentos de penuria económica, los vendieron, cambiaron e incluso utilizaron como combustible. Las casas de la corporación, parroquias, iglesias y ayuntamientos que conservaban los libros de actas, punzones, etc., fueron a menudo objeto de pillaje y posterior venta al mejor postor.

En cuarto lugar se pueden citar los incendios, abandonos de edificios, derrumbamientos y traslados de fondos.

En quinto lugar, la desamortización de Mendizábal, cuyas nefastas consecuencias a estos efectos son de sobra conocidas.

En sexto lugar está el hecho de que, ciertamente, existen hoy día algunas ordenanzas y libros gremiales, pero en lugar desconocido, mezclados con otros documentos ajenos o pendientes de clasificación, catalogación y archivo.

\section{EL GREMIO}

El siglo xirr, que es el siglo de las catedrales y de la Suma Teológica, es también el siglo del nacimiento de los gremios. El preboste de París, Étienne Boileau, por inspiración de San Luis, escribe el Libro de los oficios, en el que aparece con claridad meridiana todo lo que habrían de ser los gremios. 
Los gremios son unas corporaciones profesionales constituidas por artesanos de una localidad, dedicados a un oficio determinado, que se unen con el fin de organizar y regular su propia actividad.

El gremio tiene un fin primordial y egoísta: mantener el exclusivismo

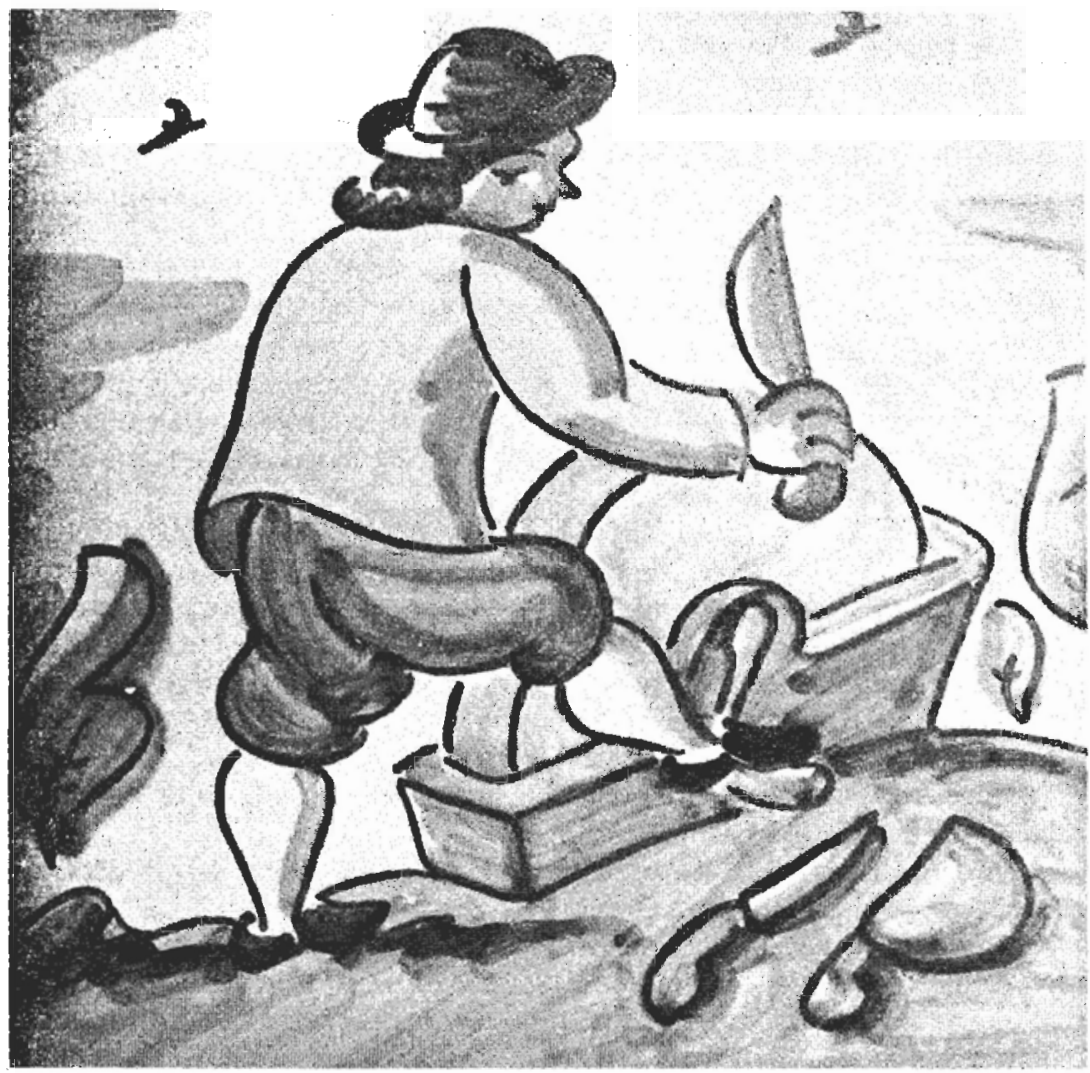

FIG. 1.-Afilador, azulejo (colección particular).

en el trabajo. No puede trabajar en un determinado oficio sino aquel que está agremiado. Así, en alguna ordenanza se llegó a decir: «Si alguien posee tienda de telas, carpintería, ebanistería o tundidoría sin pertenecer a nuestro gremio, vayamos, y por la fuerza, por la violencia, quememos la 
tienda y castiguémosle duramente» ${ }^{15}$. Y las Ordenanzas de los cuchilleros de Sevilla, recopiladas en 1632, dicen textualmente: «Y en adelante ninguna persona que no fuere maestro examinado del dicho oficio de cuchillería, ni pueda tener obrero ninguno que labre en su casa, so pena, que el que lo contrario fiziere, por la primera vez, el que tal obrero tuuiere en su casa, pague seyscientos marauedis; y por la segunda, la dicha pena y tres días en la carcel; y por la tercera, la pena doblada y sea traydo a la verguença publicamente» ${ }^{17}$.

El trabajo gremial, como la vida de entonces, era radicalmente distinto al de nuestra época. En las Edades Media y Moderna, el tiempo y el afán desmesurado de lucro no contaban. Sólo interesaba la perfección de la obra hecha, que enaltecía al gremio. En este sentido, el marqués de Lozoya se pregunta: «¿Cómo es posible que sin ser matemático se haya podido calcular una catedral gótica? ¿Cómo es posible que unos canteros, no dirigidos por un ingeniero, hayan hecho una obra que hoy, en la ingeniería, sería muy difícil de calcular? Pues a fuerza de maestría y de perfección en el oficio; a fuerza de haber recogido, desde niño, la herencia de muchas generaciones; a fuerza de haber aprendido un trabajo perfecto. De este modo, un cantero, cuyo nombre no conocemos muchas veces, y si lo conocemos, sabemos que no tenía más prestigio social que tiene un albañil de nuestros días, hacía, por ejemplo, la Lonja de Valencia, la catedral de Sevilla, la de Burgos, a fuerza simplemente de esto: de sabiduría en el oficio, sabiduría recogida en un largo aprendizaje, madurada en el tiempo de oficialía, probada por el examen y después ejercida siempre bajo una vigilancia del gremio. De aquí esos hierros admirables y esa orfebrería que nos sorprende y esas telas prodigiosas y todo lo que es artesanía medieval» ${ }^{18}$.

Pero antes de seguir adelante con los diversos aspectos que los gremios ofrecen, muchos de ellos complejos pero siempre de gran interés, y aunque caen un tanto fuera del objetivo concreto de este trabajo, conviene dar un concepto preciso de en qué consisten éstos.

Juan Regla da una definición breve de los mismos diciendo que se trata de "corporaciones sujetas a un estatuto que garantiza la vida de los artesanos como clase social autónoma» ${ }^{19}$, y García Valdeavellano ${ }^{20}$ con-

In Marqués de Lozoya, Los gremios españoles, Escuela Social de Madrid (Ministcrio de Trabajo), Madrid, 1944, págs. 7 y 8.

${ }^{17}$ Cfr. Apéndice.

" Marqués de Lozoya, op. cit., pág. 11.

1" Juan Regla Campistol, Historia general del trabajo. La época del artesanado, Apéndice: La época del artesanado en España (siglos V-XVIII), tomo II, Ed. Grijalbo, Barcelona, 1965, pág. 435.

${ }^{20}$ Luis García Valdeavellano, Curso de bistoria de las instituciones españolas, 5." cd., Ed. Revista de Occidente, Madrid, 1973, págs. 285 y sigs. 
cibe el gremio como una corporación profesional, constituida con arreglo a un estatuto escrito, reconocida como tal por el municipio de la ciudad que ejerce la inspección sobre la misma y que supone una organización

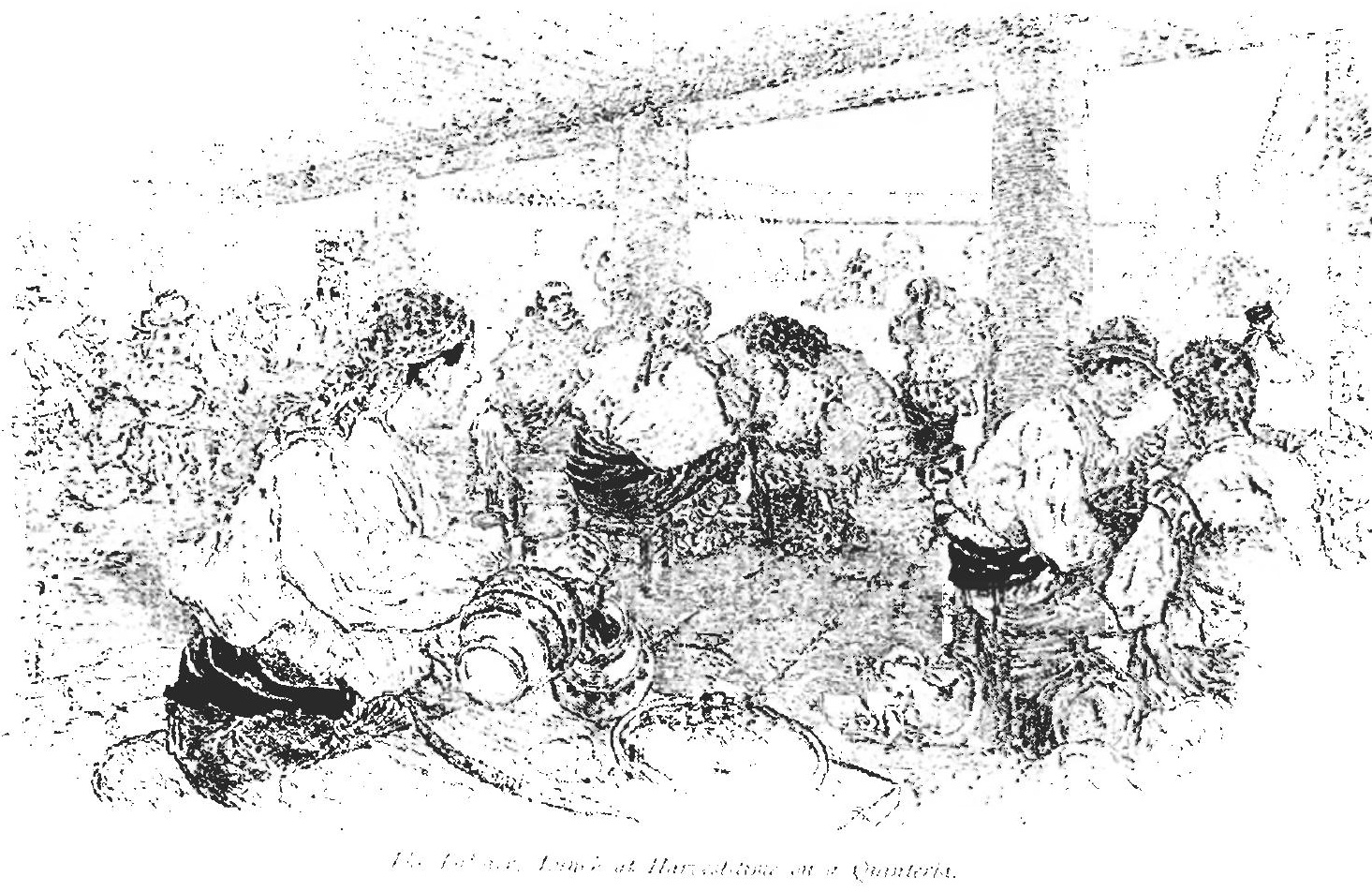

Fig. 2.-Almuerzo en una venta en época de cosecha (dibujo de Daniel Vierge en On the trail of Don Quixote, de August F. Jaccaci, Londres, 1897).

del oficio correspondiente, jerarquizada en diversos grados, integrada por un cuerpo de trabajadores unidos para el perfeccionamiento técnico de su arte y para defenderse de la competencia, investida de jurisdicción y de facultades de policía y vigilancia sobre la propia actividad. 
En cuanto al origen de los gremios, existen múltiples y muy variadas teorías sobre cuyo fondo no vamos, naturalmente, a entrar ahora; las más importantes se resumen en los que opinan que los gremios son una continuación o resurrección de los collegia de Roma, asociaciones profesionales que no tuvieron el carácter cerrado y jerárquico de que gozaron luego aquéllos; los que acercan su origen a las gildas germanas; otros que piensan que su origen está precisamente en la mezcla de ambos, collegia y gildas; como dice José María Font ${ }^{21}$, en realidad se trata más bien de precedentes o formas análogas que de una verdadera génesis institucional, aunque ésta puede admitirse en algún caso singular (Italia, Alemania). En nuestra Península, sigue diciendo, la organización gremial parece delinearse ya a principios del siglo XIII como una transformación o evolución de las cofradías (asociaciones con finalidad religioso-benéfica integradas por trabajadores de un mismo oficio). De esta misma opinión participa Lozoya $^{2}$, quien señala cómo la cofradía suele ser más antigua que el gremio, pues los trabajadores de la Edad Media se agrupan primero por razones religiosas, para celebrar la fiesta religiosa de su patrón, y después, muchas veces, las cofradías toman características gremiales; más tarde, los gremios se secularizan y queda a un lado la cofradía, encargada de las funciones religiosas y de la asistencia social; otras veces es tal la íntima unión entre los mismos, que resulta casi imposible distinguir el gremio de la cofradía.

Redondo ${ }^{23}$ se muestra inclinado por la teoría de la espontaneidad, consistente esencialmente en estimar que la agremiación nacería en el momento en que se dieran unas determinadas circunstancias fácticas y partiendo del principio de que el espíritu de asociación es de todas las épocas, y así se tendría que el «hecho y la forma» de asociarse sería siempre la misma, mientras que el «fondo y el contenido», es decir, los componentes económicos, culturales y jurídicos, cambiarían de un lugar y época determinados a otras.

Cualquiera que sea la teoría más ajustada a la realidad sobre el origen de los gremios, lo cierto es que, como siempre, existen no una, sino varias razones o causas que hicieron necesaria la institución gremial. Font ${ }^{24}$, siguiendo a Von Below, menciona las siguientes: la necesidad de limitar el número de personas dedicadas a un oficio determinado (lo que se podía conseguir fácilmente estableciendo la obligatoriedad de pertenencia al gremio e implantando un examen con elevados derechos), la manifiesta

"José María Font, Diccionario de bistoria de España, tomo II, 2." ed., Ed. Revista de Occidente, Madrid, 1968, pág. 248.

${ }_{22}$ Marqués de Lozoya, op, cit, pág. 12.

21 Guillermo Redondo Veintemillas, op. cit,, pág. 45.

${ }^{24}$ José María Font, op, cit,, pág. 249. 
conveniencia de alejar competencias molestas (mediante trabas a los trabajadores extranjeros y limitación de la producción a los agremiados), la lucha contra la gran industria (prohibiendo el excesivo número de máquinas o de materias primas), mayores facilidades para la venta, control de los productos elaborados a fin de acreditar la industria local, necesidad de procurarse materias primas a precio razonable, evitando el acaparamiento y la conveniencia de adquirir una cierta fuerza política ante la autoridad y comunidad local.

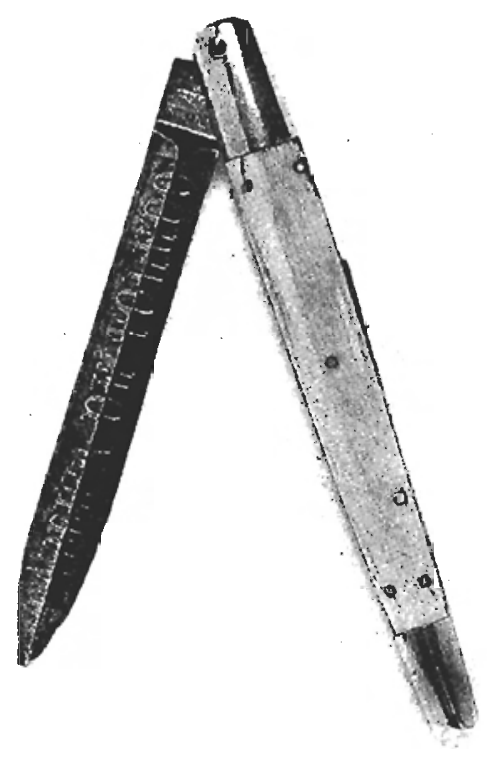

FIG. 3.-Navaja española de cachas dc marfil manufacturada en la Fábrica Nacional de Armas de Toledo, siglo XIX.

En España, cl gremio más antiguo fue el de los pelaires de Tarazona, al cual Jaime I otorgó la merced de poder ostentar las reales armas en los pendones del gremio. En 1137 existían ya en Zaragoza tres calles, denominadas de la Pellicería, Borzaría y Corregería, hecho sin duda muy significativo y demostrativo de una realidad. En 1200 se conocían en Barcelona los gremios de zapateros y chapineros; en 1211, los de canteros y al- 
bañiles; en 1255, el de fustaneros o tejedores de cotonía, y en 1257 entran a formar parte del concejo municipal de los cien prohombres, profesionales de los oficios que tenían cuerpo y matrícula formal ${ }^{25}$. Para María del Carmen Heredia, «las primeras noticias de reglamentación datan del siglo XII, siendo el gremio de labradores de La Coruña uno de los más antiguos. En la centuria siguiente se establecen los tenderos, tejedores y arrieros de Soria, que unían ya a los fines meramente religiosos otros

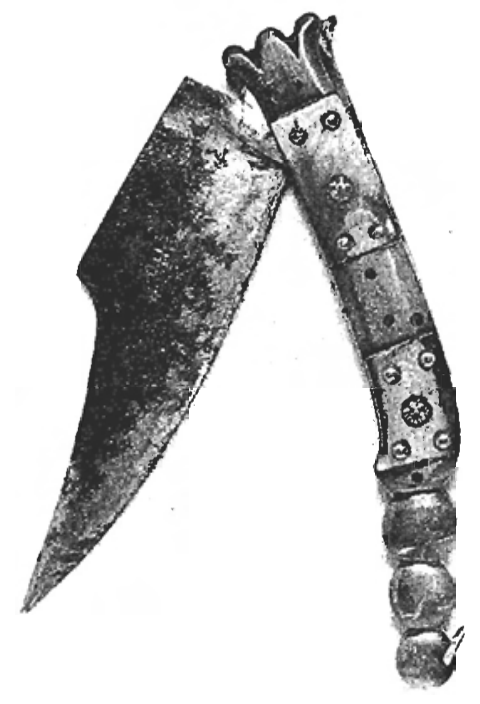

FIG. 4.-Navaja española fabricada en Huesca, siglo xıx.

de carácter económico y profesional. Por la misma época los encontramos también en Cataluña, aunque sin el hermetismo y reglamentación posteriores» ${ }^{26}$.

${ }^{25}$ Antonio del Campo y de Echevarría, Los gremios en España (Discurso), Madrid, 1904 , pág. 8.

${ }^{26}$ María del Carmen Heredia Moreno, Estudio de los contratos de aprendizaje artístico en Sevilla a comienzos del siglo XVIII, Diputación Provincial de Sevilla, Sevilla, 1974, pág. 9. Según esta misma autora, los gremios europeos más antiguos con estatutos definidos son los panaderos de Pontoise y los curtidores de Ruan, de 
Los gremios estaban plenamente establecidos en el siglo xiv en Cataluña y poco a poco «se convertirían en el elemento más activo de la vida urbana» ${ }^{27}$, como lo demuestra el hecho de que, en el siglo Xvi, eran trein-

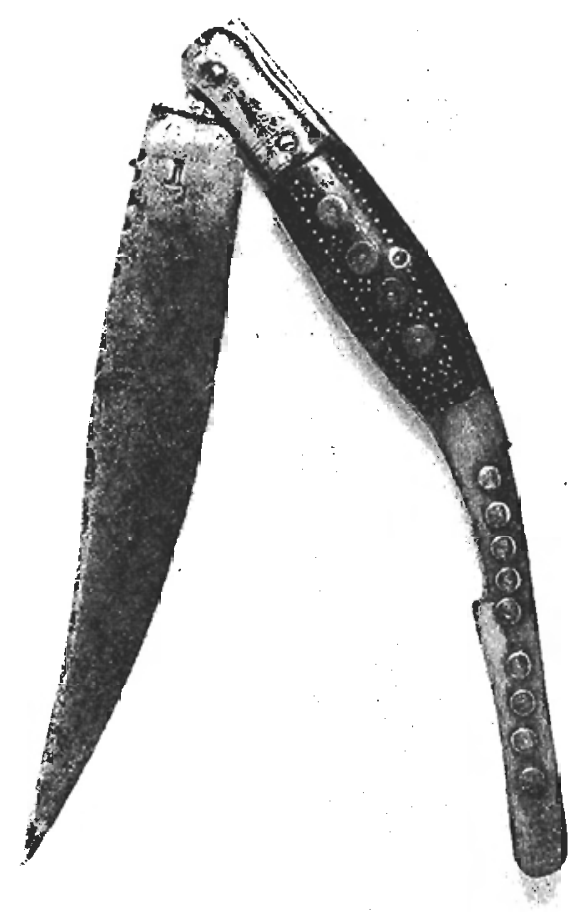

Fig. 5.-Navaja popular española del siglo XIX.

ta y siete las calles que en Barcelona tenian el nombre de un antiguo oficio, y entre ellas el de la Daguería ${ }^{28}$. Y ello no sólo en la Península, sino

1162 y 1163 (Jenn Jacques, Las luchas sociales en los gremios, Madrid, 1972, página 18), aunque reconoce que es posible que existicran otros anteriores en Flandes y Alcmania.

${ }_{27}$ Esperanza Pedraza, Espaderos toledanos, en Fábrica Nacional de Armas de Toledo, Fábrica Nacional de Armas, Toledo, 1982, pág. 166.

28 Estanislao Segarra, Los gremios, Barcelona, 1911, pág. 246. 
también en el mismo Méjico los gremios iban adquiriendo auténtica carta de naturaleza, como lo prueba el texto de Carranca cuando dice: «El doctor Francisco Cervantes Salazar, en uno de sus Tres diálogos latinos, impresos por primera vez en México en 1554, hace a Zuazo describir una parte de la ciudad de Mćxico con estas palabras dirigidas a su interlocu-

FıG. 6.-Navaja española de anilla

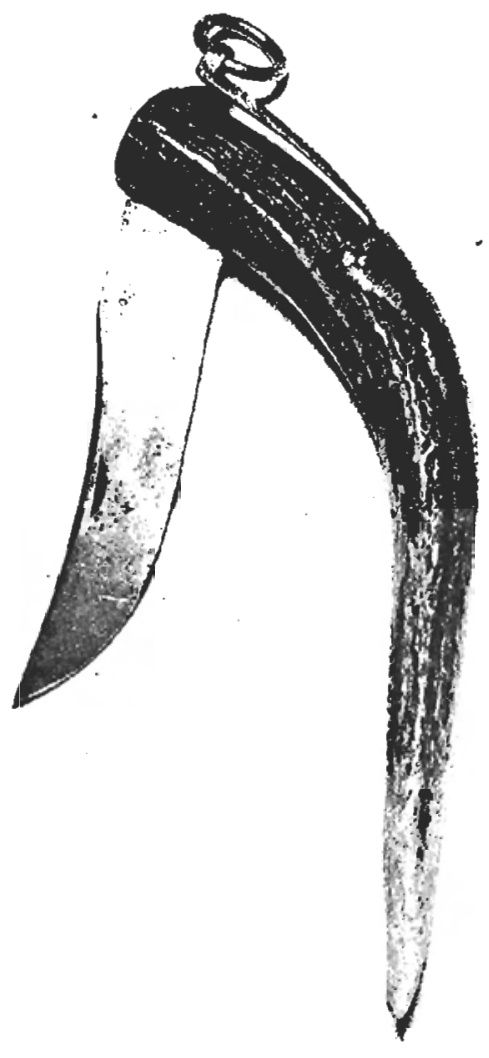
del siglo $\mathrm{xIx}$.

tor: "Desde esta calle, que como ves atraviesa la de Tacuba, ocupan ambas aceras, hasta la plaza, toda clase de artesanos y menestrales, como son carpinteros, herreros, cerrajeros, zapateros, tejedores, barberos, panaderos, pintores, cinceladores, sastres, borceguineros, armeros, cereros, ballesteros, espaderos, bizcocheros, pulperos, torneros, etc., sin que sea admiti- 
do hombre alguno de otra condición u oficio" (Reimpresión de Joaquín García Icazbalceta, México, 1875, pág. 93)» ${ }^{29}$.

El estudio de los gremios, como se dijo antes, es materia compleja y confusa por falta de ese mínimo de uniformidad y homologabilidad en el tiempo y en el espacio, que tanto ayudaría a su investigación y conocimiento ${ }^{30}$. Pese a ello, y como prueba confirmatoria de la importancia vital que tuvo esta institución en los reinos españoles, se recogen aquí los gremios que existieron en el pasado y que hoy han desaparecido ${ }^{31}$, excluyendo de los mismos los que eran simples oficios, sin haber adquirido auténtica configuración gremial, tales como aguadores, albarqueros, alfayates, alforjeros, algodoneros, aljeceros, aluderos, amasadores, aprensadores, arneseros, arqueadores, arrieros, arroberos, aserradores, bancaleros, barraganeros, barqueros, baqueteadores, barrenadores, bolicheros, broqueladores, canilleros, canteros, coleteros, colmeneros, coraleros, cordeleros, criberos, emborradores, empedradores, escribanos, esmoladores, estambreros, estañeros, fustaneros, gaiteros, hacheros, lacayos, lanceros, martineteros, moleros, oropeleros, palmeros, perchadores, pergamineros, pregoneros, rastrilleros, salitreros, sirvientes, tejeros, terreros, tinajeros, urdidores, vareadores de lana, yelmeros y zurcidores entre otros.

Así, pues, con las salvedades expuestas, se puede afirmar que los gremios más importantes a lo largo de los siglos en nuestra Patria fueron los de abaniqueros, abejeros, aguardenteros, agujeros, aladreros, alambradores, alarifes, albarderos, albardoneros, albéitares, alburjaqueros, alfamareros, alfareros, aljeceros, alojeros, alpargateros, altareros, ancoreros, anzoleros, aparejeros, arcabuceros, arcadores, argenteros, armeros, atahoneros, balancistas, ballesteros, bañadores, barquineros, bataneros, bati-

${ }^{20}$ Raúl Carranca y Trujlllo, Las ordenanzas de gremios de Nucua España, separata de la revista "Crisol», México, 1932, pág. 4.

". El siguiente párrafo es altamente significativo del confusionismo general reinante: «En el siglo xviri, los gremios, cofradías, hermandades y congregaciones aumentaron; además, no sólo contaban las que podían ostentar reglamentación escrita, sino que, dada la tendencia de exacerbación de las reglas de cierre y defensa de privativas exclusivas en los gremios del siglo anterior, muchos oficios que no contaban sino con reglas y normas manuscritas o de traclición oral actuaban como gremios, y la tradición les había hecho ser admitidos como tales por la comunidad y en ocasiones incluso por el municipio zaragozano» (José Francrsco Fornies Casals, La Real Sociedad Económica Aragonesa de Amigos del Pais, Confederación Española de Cajas de Ahorros, Madrid, 1978, pág. 55).

${ }^{31}$ No se incluyen, por tanto, las profesiones actualmente vigentes, conno son las de albañiles, almacenistas, alpargateros, botoneros, cabreros, carniceros, carpinteros, cerrajeros, cirujanos, cocineros, confiteros, curtidores, doradores, ebanistas, encuadernadores, escultores, esquiladores, grabadores, herreros, hortelanos, labradores, marineros, molineros, panaderos, paslores, pescadores, pintores, plateros, ropavejeros, sastres, sombrereros, tapiceros, torneros, elc. 
fullas, bayonetistas, belluteros, blanqueros, bodegoneros, bolseros, boneteros, borceguineros, boteros, botilleros, brosladores, buidadores, cabestreros, cajeros, calceteros, caldereros, cambiadores, campaneros, campanilleros, candeleros, cañonistas, capelleros, cardadores de lana, carruajeros, cedaceros, cereros, cesteros, ciegos, cinteros, cobreros, cocheros, colcheros,

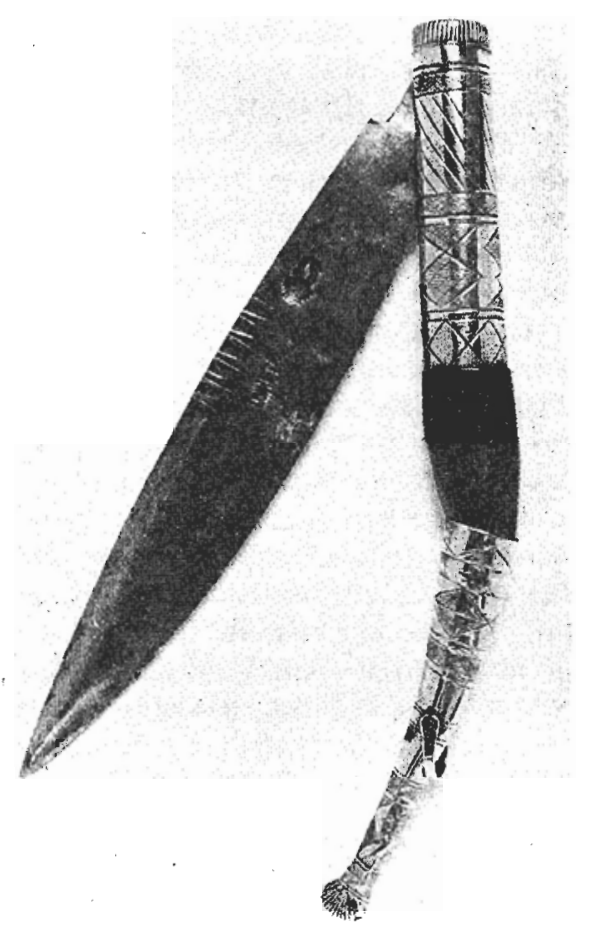

Frg. 7.--Navaja española de virola giratoria del siglo xvirI.

coleteros, comediantes, coraceros, corcheros, cordoneros, corredores de bestias, corredores de oreja, correeros, cotamalleros, cribadores, cuberos, cuchilleros, curadores, chalanes, chapineros, chisperos, chocolateros, dagueros, doradores, drogueros, embaldosadores, ensambladores, entallado- 
res, escopeteros, esgremidores, espaderos, esparteneros, especieros, estereros, feligraneros, figoneros, flamencos, freneros, fundidores, fusteros, gorreros, guadamacileros, herradores, herreros, hilanderos, hoceros, jaboneros, jalmeros, jubeteros, juboneros, ladrilleros, laneros, latoneros, lineros, linterneros, loceros, llaveros, manguiteros, manteros, mantilleros, maromeros, marragueros, medieros, menuderos, mercaderes de vara, merceros, mesoneros, montereros, mulateros, mureros, naiperos, odreros, oracioneros, organeros, orilleros, pañeros, parcheros, pasamaneros, pedreros, peinadores de lana, peineteros, pelaires, peloteros, pcllejeros, pergamineros, picheleros, plateros, polvoristas, pregoneros, puñaleros, relicarieros, lomaneros, roperos, saqueros, sarrieros, sayaleros, serradores, silleros, silleteros, sogueros, sucreros, tablajeros, tafetaneros, tañeros, tejeros, tejedores, terciopeleros, tijereros, tintoreros, tiradores de oro, tiradores de plata, toneleros, toqueros, torcedores de seda, trajineros, tundidores, vaxadores, veleros, velluteros, vidrieros, xervilleros, yeseros, zapateros de obra anciana, zapateros de obra prima, zaranderos y zurradores.

En principio, todos estos gremios contaban con su propia normativa escrita, ordenanzas (u ordinaciones) que reglamentaban la vida de la corporación y que al ser aprobadas por el municipio o el monarca - el Consejo de Castilla e incluso la audiencia o la capitanía general- quedaban plena y formalmente constituidos.

Las ordenanzas abarcaban todo el contenido de la vida gremial, y unas veces de forma más sucinta y otras in exienso, normaban cuestiones tales como la advocación a cuya protección se acogían, la prohibición de manufacturar y comerciar los objetos de competencia del gremio a quienes no perteneciesen al mismo, la limitación de ciertos instrumentos de trabajo, las jerarquías existentes y sus cometidos, las reuniones que se debían celebrar, Jos exámenes a realizar y los derechos que tenían que abonar los aspirantes, así como las piezas que preceptivamente debían fabricar éstos, las inspecciones de los obradores, las comprobaciones de las obras producidas, la ayuda asistencial, las contribuciones de los agremiados, las penas y multas, el monopolio, la adquisición y distribución de las materias primas, la prohibición de entrada en la ciudad de manufacturas semejantes a las elaboradas por el gremio, la fijación del número de maestros que podía tener la corporación, el registro de las marcas de los maestros, las prohibiciones y autorizaciones para poseer taller y tienda al público, disposiciones sobre las características técnicas de la obra producida, etc. Dentro de la mentalidad de la época, es prueba de gran honradez y belleza de miras el texto que ordenaba: «Que ningún oficial ni maestro del dicho oficio, ponga en su casa ni tienda, ni venda en ella espada quebrada por sana, sino cada cosa por lo que es o fuere, ni de vna ley por otra, ni 
vayna de carnero por de becerto, sino cada cosa por lo que fuere, porque dello vendra muy gran daño a la republica» ${ }^{32}$.

El gremio, cualquiera que sea la época y lugar en que se contemple, estaba estructurado en tres categorías: aprendiz, oficial y maestro, y controlaba el ingreso y ascenso a cada una de las mismas. En términos generales, puede decirse que el aprendizaje abarcaba un plazo de duración de dos a cuatro años, no pudiendo ingresar antes de los dieciséis. El contrato de aprendizaje consignaba las condiciones de enseñanza, alimentación y alojamiento, establecía los deberes mutuos de aprendiz y maestro y era intervenido por los jetarcas de la corporación; transcurrido el plazo reglamentario y habiendo conseguido la suficiente pericia en el oficio a juicio del respectivo maestro, el aprendiz era inscrito por el gremio en la categoría de oficial, donde tenía que permanecer un mínimo de dos años. Transcurrido este tiempo, si el oficial deseaba ascender a la categoría de maestro debía superar un examen, previo abono de unos derechos económicos, consistente en realizar ante las autoridades de su gremio una o varias obras determinadas («obras maestras»), que si a juicio de los examinadores eran correctas, le capacitaban para obtener el título de maestro, abrir taller propio y poseer empleados y punzón de marca. Los gremios procuraron siempre restringir el acceso a la categoría de maestría, en especial tratándose de forasteros y más aún cuando eran extranjeros, exigiendo unos derechos de examen más elevados y favoreciendo, por el contrario, la admisión de parientes e incluso de convecinos ${ }^{33}$.

Así, en las Ordenanzas de Sevilla, en el epígrafe referente a los cuchilleros, se dice: «Otrosi, ordenamos, y mandamos, que ninguna persona pueda ver ni use del dicho oficio de oy en adelante, ni de poner ni de assentar tienda, sin que primeramente sea examinado por los dichos veedores, juntamente con otros dos maestros, que para ello con juramento escogieren: y despues assi juntados, examinado, lo traygan y presenten ante Nos, y Nos le confirmatemos en el dicho oficio, y le mandaremos dar nuestro mandamiento para el vso y exercicio del dicho su oficio: so pena que el que de otra manera pusiere tienda, pierda la obra que assi fiziere y tuuiere, y mas pague de pena seyscientos marauedis: y que el tal hombre que se oulere de examinar pague a cada vno de los dichos examinadores por su trabajo, vn real de platà» ${ }^{34}$.

Las Ordenanzas de Toledo, de 1590, mandan que el examinando «ha de hazer y labrar las piezas susodichas, en toda perfecion, conforme a estas ordenanzas. $\mathrm{Y}$ hechas, vistas y examinadas por los dichos veedores

\$2 Ordenanzas para el buen régimen y gobierno de la muy noble, muy leal e imperial ciudad de Toledo, de 22 de diciembre de 1590 , título sesenta y tres.

33. José María FONT, op. cit., pág. 250.

34 Cfr. Apéndice. 
y examinadores, declarando ser habil y suficiente para vsar y exercer el dicho oficio de espadero, se le ha de hazer y dar su carta de examen, declarando en clla las cosas de que puede vsar el dicho espadero: lo qual quede en vn libro que este en poder del escrivano mayor del Ayuntamiento desta ciudad, para que se sepa quien se examino, y de las cosas que le dan por habil, y en el firmen los dichos veedores y examinadores» ${ }^{35}$.

En Zaragoza, las Ordenanzas de 1591 pedían al aspirante a maestro que fabricara «una cuchillera con dos cuchillas grandes una roma, y otra de punta caida, y estas piezas debian ser forjadas de baquete, esto es calzadas de cazo, y filo de acero; y à mas otras tres piezas, que eran un tenedor, un cuchillo mediano de trinchar, y otro mas pequeño. Mas: una caxa de fraile con tixeras de gozne, dos cuchillas tingladas con nutias de laton, y cahacados de trasin, con un cortaplumas de lo mismo: una lanceta para cerrar cartas, que salga del mismo cuchillo, y dos pares de tixeras unas de escritorio, y otras de barbero" ${ }^{35}$.

Finalmente, en los estatutos de la Cofadría de San Eloy, presentados en 1770, para su aprobación, al Consejo de Castilla, se puede leer: «haran fabricar a la tal persona unas tigeras de tendero de paños, un cortaplumas, dos cuchillos de mesa a la inglesa, haziendo los puños, vulgarmente nombrados $a b$ dolsas, aviendo de asistir los referidos examinadores quando y en la ocasión se fabricaran u trabajaran dichas cosas, pagados y satisfechos de su condecente salario por la tal persona querrá ser examinada. Tasado dicho salario por los priores de dicha cofradía que en dicha ocasión fueren. Otrosí, estatuyen y ordenan que todos los hijos de qualquier maestro daguero de la presente ciudad y cofradía querrán ser examinados por ser maestros dagueros de la misma ciudad y cofradía, los examinadores que para dicho examen serán elegidos y nombrados vistos; a excepción, empero, del hijo primogénito de los tales maestros, que únicamente le harán o deverán hazer fabricar un cortaplumas» ${ }^{37}$.

Los jerarcas de los gremios eran elegidos - por insaculación o elección por mayoría - por la propia corporación reunida en capítulo o junta general, y consistían esencialmente en unas autoridades superiores que eran las que de hecho gobernaban - «alcaldes» en Andalucíd, «sobreposats» en Baleares, "clavarios» en Aragón, «cónsules» en Valencia, «mayordomos» en Aragón y «veedores» en Castilla_-, una junta asesora y el capítulo o cabildo general. De estas autoridades gremiales es de especial

"Ordenanzas de Toledo, op. cil.

36 Ignacio Jordón de Asso y vel Río, Historia de la econonía política de Aragón, C. S. I. C., Zaragoza, 1947, pág. 130.

${ }_{37}$ Ramón Pianes Albets, L'activital industrial a Solsona durant el segle XVIII. Una primera aproximació, separata de «Cardener», núm. 1 (diciembre 1983), pág. 119, Institut d'Estudis Locals de Cardona (cfr. Apéndice). 
interés la institución del veedor, que, en general, tenía entre otras funciones las de examinar a los aspirantes y, sobre todo, la de inspeccionar los talleres artesanos y las tiendas a fin de comprobar si las disposiciones técnicas recogidas en los estatutos eran debidamente cumplidas.

En las Ordenanzas de Sevilla se dice textualmente: «ordenamos y mandamos que todos los maestros y oficiales del dicho oficio, el dia de señor Sant Iuan-Baptista, de cada vn año, se ayunten en su hospital, o en otro lugar que para ello señalen, y de vna vnion y conformidad, elijan entre si dos personas de los mass sabidores y expertos en la dicha arte, y de mejor conciencia, que en el dicho oficio aya, para que estas dichas dos personas sean, el vno Alcalde, el otro veedor del dicho oficio el año, porque assi los eligieren.» $Y$ en otro apartado posterior se fijan las obligaciones de los veedores, al decir que éstos «con mucha diligencia caten y examinen las dichas tiendas, y las obras tocantes al dicho oficio de cuchilleria, que fallaren en las tiendas de los dichos maestros oficiales del dicho oficio y otras quales quier personas que las tuuieren para vender, o tuuieren colgadas, o puestas en las dichas sus casas y tiendas las vezes todas que quissieren y fueren justo especialmente, que alomenos caten las dichas casas y tiendas, y examinen las dichas obras doze vezes en el mes. Y las obras que fallaren excessiuas, y contra la forma y tenor destas dichas ordenanças, las saquen de poder, o poderes de quien las fallaren, y las traygan ante Nos en el mesmo dia, porque Nos fagamos en el caso lo que sea justicia. E assi mismo mandamos, a todos los oficiales y ottas qualesquier personas en cuyo poder fallaren las dicha obras para vender, que cada y quando que los veedores, o alguno dellos les fuere a ver sus obras, fagan sus casas llanas, y sin ningun temor les dexen catar todas las obras de la cuchilleria so pena de dos mill marauedís y nueue dias en la carcel» ${ }^{38}$.

A veces, las penalizaciones de la inspección eran benignas, como en el caso de las Ordenanzas de Cartagena, de 1736, donde se dice «que siempre que cualquiera pieza u obra de los dichos maestros se hallare falsa, viciada o en otra forma defectuosa según los veedores, deban recurrir al maestro que la ha hecho dando a la parte otra pieza de bondad y calidad a su propia costa» ${ }^{34}$. Otras veces el castigo por incumplimiento de la normativa gremial era mucho más riguroso, ya que llevaba aparejado penas pecuniarias y de privación de libertad.

La consideración social y estimación individual del cargo de veedor evolucionó con el transcurso del tiempo, pues, en ocasiones, el carácter

28. Cfr. Apéndice.

${ }^{39}$ Ordenunzas de cerrajeros, berreros, cuchilleros y escopeteros, recogidas por Eduardo Cañabate Navarro en Ordenanzas de los gremios de Cartagena en el siglo XVIII, Academia Alfonso X el Sabio, Murcia, 1962, pág. 26. 
de preeminencia social era manifiesto, y en otras, los interesados deseaban liberarse de lo que más que cargo era carga.

Ejemplo del primer caso es el nombramiento por el rey Carlos II de veedor perpetuo a su cuchillero real, cuando dice: «Por quanto por parte de Don Agustín López, cuchillero de mi Real Casa, me ha sido hecha relación, que es estilo, que los oficiales de ella tengan el privilegio de ser en sus gremios, veedores y examinadores por los días de su vida, como al presente lo gozan el cerrajero... he tenido por bien de benir en ello y en su conformidad mi voluntad es que vos, el dicho Agustín López seais veedor y examinador del Gremio de Cuchilleros de mi Corte por los días de vuestra vida y useis y ejerzais este oficio en la forma según y en la manera que lo ussan y exerzan los demás veedores y examinadores y mando a los alcaldes de mi Casa y Corte reciban de vos juramento en forma... y os guarden y hagan guardar todas las honras y gracias merecidas, franquezas, libertades, exenciones, preheminencias, prerrogativas he inmunidades y todas las otras cossas que por razon de dicho oficio debereis hacer y gozar... a 11 de Mayo de 1695», según consta en el Archivo Histórico Nacional ${ }^{40}$.

Por otra parte, como se dijo, existen documentos que afirman lo contrario, pues en los años 1717 y 1733 algunos veedores que ejercen dicho cargo solicitan de las autoridades que, dado que ha transcurrido con creces el tiempo reglamentario para el ejercicio de dicha función, se convoque junta general a fin de nombrar nuevos veedores que les sustituyan ${ }^{41}$.

También tenemos constancia escrita de una petición formulada por los veedores del gremio de cuchilleros de Madrid, para que, en los casos en que existan bienes, se les abonen ciertos derechos por los reconocimientos efectuados, dado que en estas «ocupaciones invierten muchas mañanas con detrimento de sus labores y por consiguiente de sus familias en esta atención»"2.

Los gremios, como toda institución social, precisaban de suficientes medios económicos para subsistir. Estos ingresos podían ser bien ordinarios, como los derechos de examen, las cotizaciones periódicas de los agremiados, las multas por infracciones y los provenientes de la posesión de censos, rentas e inmucbles, o bien extraordinarios, tales como las donaciones y los legados testamentarios. Es difícil saber hasta qué punto estos últimos eran frecuentes e importantes, aunque según Bonnassie ${ }^{43}$ hay

* A. H. N., Sala de Alcaldes, año 1695, fol. 123.

*A. H. N., Sala de Alcaldes, año 1717, fol. 109, y año 1733, fol. 65.

42 A. H. N., Sala de Alcaldes, año 1798, fols. 473-474.

${ }^{4}$ Pierre Bonnassie, La organización del trabajo en Barcelona a tines del siglo XV, Universidad de Barcelona-Instituto de Historia Medieval (C. S. I. C.), Barcelona, 1975, pág. 50. 
que pensar que sí lo eran, pues no hay privilegio gremial que no invite a sus miembros a dejar cierta suma a la comunidad en el momento de la muerte: "Item plàcia a cascun confrare en son darrer testament, fer leixa a la dita almoyna segons Déu li metrà en son enteniment, e açò no mete en oblit», según reza un documento de los daguers existente en el Archivo Histórico de la Ciudad de Barcelona ${ }^{44}$.

Los ingresos por multas no debían ser despreciables, cuando en 1590 las Ordenanzas de espaderos de la ciudad de Toledo, en su último párrafo, dicen textualmente: «Y los que fueren contra las dichas ordenanzas en lo demas, por cualquier cosa dello caygan en pena de trezientos marauedis, y perdida la obra que se les hallare contra las dichas ordenanzas. Los quales se repartan en esta manera, tercia parte para el reparo de los muros de esta ciudad, y tercia parte para el denunciador, y tercia parte para el juez o juezes que lo sentenciaren» ${ }^{45}$. Y la Corona misma, siempre tan necesitada de numerario con que atender a sus empresas, estipula que «en las Ordenanzas que en lo sucesivo se formaren en esos Pueblos para su mejor administración y govierno, sin excepción de las de los Gremios, las penas que se impusieren se apliquen a la Cámara en la parte que le corresponda, y en las Ordenanzas ya probadas, se aplique una cuarta parte al mismo destino" ${ }^{46}$.

Un aspecto económico importante del funcionamiento del gremio de cuchilleros que es de interés mencionar es el de la participación de todos los maestros del mismo, en proporción a su capacidad de producción, en las materias primas y elementos materiales necesarios para la elaboración de sus armas blancas. Así, en las Ordenanzas de Toledo se dice que «qualquier maestro examinado, que comprase qualquier mercaderia tocante al oficio en junto, sea obligado a dar parte dello a qualquier maestro examinado del dicho oficio, que se lo pidiere, por el precio que lo huuo, sin lleualle interes ninguno, dentro de tercero dia que jurare auello sabido» ${ }^{47}$, y las Ordenanzas de Sevilla mandan «que si algun maestro o oficial del dicho oficio comprare azero o fierro o otra obra qualquiera, tocante al dicho oficio de vn quintal arriba, assi en la dicha cibdad como fuera della, dentro del termino de las cinco leguas, que den parte a los otros oficiales del dicho oficio, rata por rata, lo que a cada uno dellos cupiere, por el tanto quanto le ouiere costado, pagando las costas que les cupieren» ${ }^{48}$. En idéntico sentido se manifiesta un documento de 6 de marzo de 1696, en el que Matheo Pérez y Agustín López, veedores y examina-

44 Gremios, privilegio en pergamino, sin clasificar.

t5 Ordenanzas de Toledo, título sesenta y tres: «De los espaderos».

+ A.H. N., Consejos, libro 1480, núm. 8.

${ }^{47}$ Ordenanzas de Toledo, título sesenta y tres: «De los espaderos».

+8 Cfr. Apéndice. 
dores perpetuos del Gremio de Cuchilleros, y Marcos de Vega y Francisco Imaz, veedores y examinadores también, exponen cómo desde tiempo inmemorial ha sido estilo en dicho Gremio que viniendo piedras de amolar a esa Corte se dé cuenta a los veedores del dicho Gremio y éstos pasen a ajustarlas con los dueños a los precios de mayor comodidad y a repartirlas conforme sus necesidades, siempre que vengan en abundancia, pues viniendo pocas se sortean entrando todos los maestros en suerte, lo que es muy conveniente para evitar discusiones y disensiones en el Gremio e impedir el alza de los precios de las piedras ${ }^{49}$.

Prácticamente lo mismo viene a expresar otro documento del mismo año en el que se dice: «Notifíquese a Domingo Gonzalez maestro cuchillero que las piedras de amolar que trujere de su cuenta a esta Corte para efecto de venderlas, no lo haga sin dar cuenta a los veedores y examinadores para que estos las repartan entre todos los demás maestros de dicho Gremio que las hubiesen menester con igualdad pagándolas por el coste con tal que se recibieren sin alterar el precio regular de ellas, como ha sido uso y costumbre en dicho Gremio, y que de aquí en adelante se ejecute lo mismo con todas las demas piedras que viniesen de venta. Los Señores Alcaldes de la Casa y Corte de su. Magestad lo mandan en Madrid a tres días del mes de Marzo de 1696.» Y Domingo González contesta diciendo que entre él y Thomas Sánchez trajeron veintiséis piedras de amolar por su cuenta, compradas con su dinero, para el gasto de sus casas y tiendas y no para revenderlas ${ }^{50}$.

Una de las características del trabajo gremial era la perfección intrínseca de sus obras. Era preciso hacer las cosas perfectamente bien, había que prestigiarse y conservar esta fama, no sólo por propia satisfacción, sino como medio de subsistir personalmente y desarrollarse como empresa. Para su logro, la función inspectora de los veedores, como se dijo, resultaba fundamental, ya que en la práctica eran los brazos ejecutores de las normas técnicas establecidas en las ordenanzas y el medio de conseguir ese perfeccionismo tan buscado entonces y tan admirado hoy.

Ya se vio cómo las Ordenanzas de Cartagena establecían que ante una obra «falsa, viciada o en otra forma defectuosa» había que ir al maestro que la hizo y exigir la entrega de otra de «bondad y calidad» ${ }^{51}$. Y entre los spasers estaba prohibido guarnecer de nuevo espadas rotas, y si se quería repararlas a toda costa, tenían que venderlas en vainas viejas para no engañar al cliente ${ }^{\overline{2}}$.

4. A. H.N., Sala de Alcaldes, año 1696, fol. 51.

A. H. N., Sala de Alcaldes, año 1696, fols. 52 y 53.

$\$$ Cfr. nota 39.

5Pierre Bonnassie, op. cit., pág. 143: Archivo Histórico de la Ciudad de Barcclona, Ord. IV, 10, fol. 75; Crides, caja 17, año 1474. 
Uno de los medios más eficaces que el gremio de cuchilleros $-\mathrm{y}$ los demás gremios también, naturalmente- tenía para salvaguardar la calidad de sus obras era la grabación del cuño, contraste, punzón o marca sobre las mismas. Su utilización era obligatoria — «en las quales obras los dichos maestros pongan sus señales porque sean conoscidas quien las fizo» ${ }^{53}$ - y Sancho Seral observa que «el artesano estaba obligado a «sellar con sello de sus armas» la obra que ejecutaba o la mercancía que ofrecía al público; de este modo se impedía, además, que un artesano revendiese como suya la obra hecha por otro. La falta de esta marca, que representaba ya por sí una desobediencia y hacía sospechar de un probable fraude, era castigada con penas pecuniarias a favor de la corporación y, en ocasiones, del municipio, del tesoro real y de las instituciones benéficals. Todavía hoy se conservan bellos y recios arcones en instituciones culturales públicas españolas y extranjeras, en las que se custodiaban las diferentes marcas grabadas en planchas de metal de los artesanos agremiados, cuyas tres o más llaves estaban en poder de diferentes jerarcas del gremio a fin de evitar deshonestas manipulaciones y perjuicios económicos ${ }^{54}$.

El punzón — senyal, en catalán - es como la firma del artesano y, por tanto, inalienable y hereditario, pues la marca es el signo representativo de una familia o de una «casa». Cuando un maestro muere, su marca pasa a ser propiedad del hijo mayor si éste ha superado las pruebas del examen; si no, los cónsules retienen en depósito hasta el día en que el heredero sea juzgado digno de continuar el trabajo de su padre ${ }^{55}$.

Esperanza Pedraza, en una conferencia sobre los espaderos toledanos, recuerda cómo «en las cortes que se celebran en Madrid el año 1567 acuden los procuradores de la ciudad de Toledo y se quejan al Rey diciendo que se introducen espadas de otros reinos con contrastes de maestros muy afamados de Toledo y los que las compran son defraudados por ser falsas imitaciones». Finalmente, «el Rey manda que no consientan ni den lugar a que se metan espadas algunas en estos nuestros reinos, de fuera de ellos, y que las hechas en Toledo traigan la marca y señal del maestro que las hubiere hecho y fabricado y del lugar donde son hechas, y el que lo contradijere, sea tenido por falsario y pierda las dichas espadas» ${ }^{56}$.

Al hablar del origen del gremio, ya se ha indicado que en la mayoría de los casos había sido la cofradía el auténtico embrión de aquél, pues el

"Ordenanzas de los cuchilleros de Sevilla; cfr. Apéndice.

" Rafael Martínez dei. Peral Fortón, Ciento calorce punzones de navaja, Ed. Almarabú, Madrid, 1985, pág. 11.

"Pierre Bonnassie, op. cil., pág. 67.

${ }^{56}$ Esperanza Pedraza, Espaderos toledanos, en Fúbrica Nacional de Armas de Toledo, Fábrica Nacional de Armas, Toledo, 1982, pág. 167. 
móvil religioso estaba profundamente enraizado en el alma medieval. Este espíritu religioso-gremial perduró a lo largo de los siglos, aunque debilitándose paulatinamente, y así vemos cómo en 1771 «el Gremio de Cuchilleros, vulgo Dagueros, que tiene privilegio Real, haze dos fiestas cada año en la Parroquia Iglesia de San Justo y San Pastor a Nuestra Señora de Esperanza, y otra a San Eloy con cuarenta horas, para las que gasta unos treinta y seis maravedíes, que se recogen de las limosnas que hazen los individuos del mismo Gremio» ${ }^{3}$.

Sin embargo, no toda la doctrina está de acuerdo con la idea que se acaba de exponer de que los móviles puramente religiosos fuesen el origen de la cofradía y posteriormente del gremio. Uña y Sarthou ${ }^{58}$ considera que el fin esencial de la cofradía no es precisamente el religioso y el piadoso, sino la propia asociación en sí, que obedece a la necesidad de robustecerse como clase para tomar parte activa en la marcha general de la sociedad, y no permanecer inerte o extraña a la vida comunitaria. En la época medieval e incluso después, el hombre como tal hombre no tenía los medios materiales ni jurídicos para el completo desarrollo de su actividad; de ahí nace la necesidad de unirse con los que tiene una inmediata relación y una problemática semejante. La religión es el vínculo que sirve para aceicarle a sus compañeros, es la fórmula de la relación; pero lo que ellos persiguen es la unión misma, para hacer frente a lo que se les opone y para perseguir sus propios objetivos. No se unen tanto para rezar a un santo, sino para, ante un santo, perseguir sus fines sociales, económicos y políticos. Por ello, cuando la unión se logra, ésta inquieta al poder público, y algunas veces son objeto de persecución, como ocurrió con Alfonso I en 1330, año en que se ordenó que las cofradías de los menesteres fueran deshechas porque eran «á deservicio del Señor Rey é á daino grant del pueblo».

La función asistencial estaba también incluida dentro de las finalidades del gremio. Había que ayudar a la viuda y a sus hijos menores, sufragar los gastos de funeral y de entierro e incluso colaborar económicamente en caso de enfermedad, etc. Todo ello, con las variaciones propias de lugar y época, estaba reglamentado, a veces minuciosamente, en los estatutos que regían la vida del gremio. En el mismo informe que se acaba de citar de la Corona de Aragón de 1771, al hablar de la labor asistencial del gremio de cuchilleros, se dice que tendrán que pagar «semanalmente seis

"A.H. N., Consejos, núm. 7.106, Expediente de la Corona de Aragón sobre el estado de las Cofradías, Hermandades, Congregaciones y Gremios de la ciudad de Barcelona y demás pueblos del Principado de Cataluña, contestando al Acuerdo de 17 de Octubre de 1770 del Conde de Aranda.

5: JuAn UÑa y Sarthou, op. cit., págs. 141 y sigs. 
dineros de cuyo fondo se les asiste cuando están enfermos» ${ }^{59}$, y los $d a$ gucrs de Barcelona, en 1517, tenían establecido que si un miembro del gremio, en el curso de un viaje por mar, era hecho cautivo, sus cónsules estaban obligados a preocuparse por su rescate y a poner a su disposición la caja común con tal que el interesado hubiese pagado regularmente sus cuotas hasta el momento de su partida ${ }^{\text {so }}$.

En su época, los gremios cumplieron a la perfección su importante función económica y social, pero en los últimos siglos de la Edad Moderna les llegó también su crisis traducida en un estancamiento, decadencia paulatina y desaparición, siendo superados por nuevas tendencias industriales, econónicas y sociales y por afanes e ideas muy distintas de las que hasta entonces habían imperado, provenientes de naciones que figuraban a la cabeza del progreso humano ${ }^{6 t}$.

Las verdaderas debilidades de los gremios, como observa Domínguez Ortiz ${ }^{62}$, fueron la progresiva rigidez de sus ordenanzas, su inadecuación a los cambios económicos y su absoluta falta de solidaridad que los hacía incapaces para una acción colectiva. Sólo algún gremio -como, por cjemplo, el de los plateros- tcnía una organización de ámbito nacional; los demás eran estrictamente locales, y lejos de ayudar al compañeto que llegaba de otra población, le ponían todas las dificultades posibles para establecerse. Incluso entre los gremios de una misma ciudad las relaciones eran poco cordiales, con abundantes rivalidades profesionales y frecuentes pleitos. Los obstáculos a todo progreso, a toda mejora en la fabricación resultaban absurdos cuando en Europa ya se había despertado la fiebre de los inventos mecánicos. Las leyes sobre los títulos de los maestros, exámenes, obra maestra, inspección y tasa de productos que en principio se habían creado para defensa de los derechos del consumidor se habian convertido en armas de estrecho egoísmo gremial.

Las exigencias de limpieza de sangre, buena conducta y determinada edad para la aceptación de aprendices, la limitación del número de maestros, la preferencia de los familiares a los forasteros y extranjeros, la prohibición de utilizar ciertas herramientas o sobrepasar la cantidad máxima autorizada de las mismas, junto con las disposiciones reales a partir de Felipe V, aumentadas con Carlos III y Carlos IV ${ }^{43}$, tendentes a suprimir

5. Cfr. nota 57.

(9) Pierre. Bonnassie, op. cit. pág. 135.

"Francisco Torrella Niubó, Gremios y Cofradias, Cámara Oficial de Comercio e Industria, Tarrasa, 1961, pág. 57.

"2 Antonio Domínguez Ortiz, La socicdad española en el siglo XVIII, Instituto Balmes de Sociología, Departamento de Historia Social (C. S. I. C.), Madrid, 1955, píg. 207.

".3 En el A.H. N., Sala de Alcaldes, año 1790, fol. 1522, se encuentra un escrito del conde de Campomanes, de 18 de agosto de 1790, que dice: «El Rey se ha digna- 
la preponderancia sociopolítica que los gremios tenían en los municipios ${ }^{64}$, todos estos factores desembocaron en unas apasionadas polémicas sobre la conveniencia o no de mantener los gremios, motivando su supresión en 1813. Si bien en 1815 fueron restablecidos ${ }^{65}$, la institución estaba herida de muerte, pues tras diversas modificaciones en los años posteriores, limitando sus atribuciones y categoría, fueron de nuevo y definitivamente abolidas en 1836, pasando, en general, cada gremio a convertirse en una

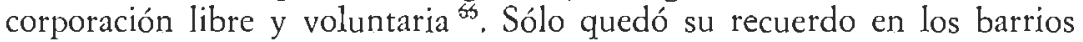
de rancio sabor añejo de ciertas ciudades, pues son frecuentes los nombres de calles como de Las Armas, de La Navaja, de Las Navajas, de Los Dagueros, de Los Puñaleros, de Los Cuchilleros, de Los Tijereros, de Los Navajeros, o de algún callejón o travesía llamado de La Ferrería o Coltellería.

\section{EL GREMIO DE CUCHILLEROS A LO LARGO DE LOS TIEMPOS}

Hasta aquí se ha contemplado sucintamente la trascendencia, estructura, funciones, nacimiento, vida y muerte de los gremios como institución social, refiriéndonos en todo lo que ha sido posible al gremio de cuchilleros con el fin de enmarcar histórica y ambientalmente éste, dedicado a la fabricación de cuchillos, puñales, navajas y tijeras esencialmente. A continuación se procederá al estudio - en la medida en que los datos históricos lo permitan — de la historia del gremio de cuchilleros conside-

do havilitar a Raymundo Antonio Santos de nación portugués y establecido en esta Villa (Madrid) para que libremente pueda travajar en su oficio de cuchillero y lo mismo que qualquiera otro que acreditase tener este ejercicio a consulta de la Junta General de Comercio, Moneda y Minas, sin que el Gremio de Cuchilleros le pueda poner impedimento. Lo que participa a V. S. para su inteligencia y que la Sala de $\Lambda$ lcaldes disponga su cumplimiento y que no se admita en ella recurso alguno de oposición a este asunto.»

ti2 Así, el libre cstablecimiento de los extranjeros en territorio español (1772), el cjercicio de la profesión sin examen previo (1790), la exención de exámenes a los extranjeros. la posibilidasl de examinarse para maestro sin haber pasado por los grados inferiores de aprendizaje y oficialía (1798), el ejercicio de dos o más profesiones simultáncamente (1791), etc.

${ }^{65}$ Circular de 29 de junio de 1815: «Habiendo decretado las Cortes estraordinarias en 8 de Octubre de 1813 que era libre a todos los naturales y estrangeros establecidos y que se estableciesen la facultad de egercer toda la industria ú oficio útil. La necesidad de examen, título ni incorporacion á los Gremios respectivos, con cuya ilimitada libertad se ha cortado la policía civil y particular que causaban entre los del Gremio sus respectivas ordenanzas y sabias precauciones que por ellas se establecían en beneficio público y fomento de las artes y de los que las egerciesen; se ha servido el REY nuestro Señor revocar dicho decreto de las Cortes estraordinarias de 8 de Octubre de 1813 , y mandar se restablezcan las ordenanzas gremiales...»

fó Francisco Torrella Niubó, op. cit., pág. 60. 
rado de forma unívoca, y para ello parece que de los varios sistemas posibles que brinda la metodología científica, el más idónco en el presente caso es el cronológico, por lo que se van a enumerar sucesivamente las informaciones y datos cuya veracidad histórica no ofrece duda, para que por primera vez queden aunados y sacados a la luz pública los exclusivamente referidos al gremio de cuchilleros.

Esta metodología obliga a ir saltando de una región a otra, de un tema concreto a otro, que quizá poco tenga que ver con él, y a pasar de algo completo y unitario, como son unas ordenanzas, a un simple dato histórico como pueda ser la existencia de cierto maestro cuchillero en un lugar determinado. Si la documentación que ha llegado a nosotros fuera suficientemente amplia, se podría hilvanar un estudio por temas concretos o por regiones españolas, pero la manifiesta escasez de estos datos, tal y como se anticipó en la introducción, no permite otro tipo de exposición.

$$
* * *
$$

1283 Iniciamos este estudio histórico con Pedro II, que el 1 de diciembre de 1283, al confirmar por carta los Fueros de Valencia, habla por primera vez de los cultellarii et baynarii ${ }^{67}$.

1366 En Zaragoza, en «la Cuchillería» de la parroquia de Santiago, existen buenos cuchilleros que dan nombre a una zona de ese barrio, entre los que se encuentra Pascual Martínez de Lérida, muerto en 1366, y el mangador Antón de Manresa, que trabajaba en $1378^{\text {'x }}$.

1392 En Valencia, el gremio de cuchilleros figura en las procesiones públicas organizadas por la ciudad para la conmemoración de algún suceso memorable o para recibir a los reyes y magnates en sus entradas solemnes, tal y como fue el caso de don Juan I y doña Violante, en que coltellers y bayners, que figuraban en quinto lugar, llevaban liurea de drap vermell sembrat de roselles de lata dor ${ }^{\text {k9. }}$.

1393 Entre las artesanías que existían en Zaragoza en 1393 se encontraba la de la cuchillería con Pedro Jijón de la Cueva ${ }^{70}$.

1412 El gremio de cuchilleros entra a formar parte del Consejo Gene-

67 Archivo de la Corona de Aragón, Colección de documentos inéditos, t. VIII, pág. 156; según José Ibarra y Folgado, Los gremios del metal en Valencia (Tesis), Facultad de Filosofía y Letras, Sección de Historia, 1919, pág. 17.

* Angel Canellas López, Zaragoza medieval (1162-1479), en Hisioria de Zaragoza, tomo I, Ayuntamiento de Zaragoza, Zaragoza, 1976, pág. 333.

${ }_{69}$ Archivo Municipal de Valencia; según Vicente Ferrán SAlvador, Capillas y casas gremiales de la ciudad de Valcencia. Valencia, 1922, pág. 44.

i Angel Canellas lópez, op. cil., pág. 364. 
ral de Valencia (órgano deliberante y popular, semejante al Consejo de Ciento de Barcelona) en $1412 \%$.

1413 Zaragoza, en 1413, ya contaba con cofradía de cuchilleros. Resulta curioso observar que tres historiadores aragoneses: Ximénez de Embún ${ }^{72}$, Canellas ${ }^{73}$ y Sancho Seral ${ }^{74}$, mencionan este hecho en sus escritos.

1420 El 19 de julio de 1420 son aprobadas las Ordenanzas de los coltellers y bayners en el reino de Valencia ${ }^{75}$.

1423 En Zaragoza, el gremio de cuchilleros logró la aprobación de sus primeros estatutos en 1423 por la reina María, esposa de Alfonso $\mathrm{V}$, el Magnánimo, quedando la corporación bajo la advocación de San Antonio. Se trataba de combatir la decadencia de sus manufacturas, pues se cometían fraudes empleando aceros de Génova y Lombardía en vez del navarro, que era el usado tradicionalmente; se prohibió la venta de ferruzas doradas de zazo y mosquero, que se vendian por otras tierras, anunciadas como de fabricación zaragozana, y se señalaron las características técnicas para la fabricación de cuchillos y la cantidad máxima de ellos que podía hacer cada oficial al día ${ }^{76}$.

1457 El 17 de mayo de 1457, el gremio de cuchilleros de Valencia establece que el aprendiz no puede pasar a otro amo sin haber cumplido el contrato con el primero y mediante licencia que éste debe darle; en el caso en que el amo se resistiese a darla, se puede acudir a los mayorales, quienes darán el permiso ${ }^{\pi}$. Asimismo, se acuerda que los oficiales de este gremio deberán permanecer cuatro años practicando ${ }^{78}$ y que el pago en concepto de derechos de examen ascienda a una libra, y ello tanto para los de Valencia como para los de fuera ${ }^{77}$.

$"$ Luis Tramoyeres Blasco, Instiuciones gremiales, su origen y organización en Valemcia, Ayuniamiento de Valencia, 1889, pág. 323.

iz Tomás Ximénez de EMBún, Descripción bistórica de la antigua Zaragoza y sus lérminos manicipales, pág. 23.

7." Anglil. Chnellas López, en Historia de España, dirigida por Menéndez Pidal, tomo XV, pág. 517.

7 Martín Luis Sancho Seral, El gremio zaragozano del siglo XVI. Dalos paro la bistoria de la organización corporativa del trabajo en España (Tesis), Ed. Tipografía la Academia, Zaragoza, 1925 , pág. 33.

7 Archivo Municipal de Valencia, Manual de Consells y Establiments, A 27 $(1418-1423)$, fols. 237-238.

76 Angel Canellas López, Zaragoza medieval (1162-1479), op. cit., pág. 404.

77 Archivo Municipal de Valencia, Manual de Consells y Establiments, núm. 37 (36 A), fol. 179; según José María Ibarka y Folgado, op. cit., pág. 28.

7s Ibillem, pág. 34.

Ibídem, pág. 40. 
1477 Los collellers de Valencia determinaron el 31 de julio de 1477 que el oficial forastero pagase cuatro sueldos de entrada y cuatro al año, de cuyo pago sería responsable el maestro ${ }^{80}$.

Se puede concluir este siglo $\mathrm{xv}$ diciendo con orgullo, y siguiendo al conde de Cedillo en su discurso de ingreso en la Real Academia de la Historia, que «de los talleres de nuestros armeros salían también hermosos productos de cuchillería y tijerería fina, que fueron muy estimados» ${ }^{8 !}$.

1512 Los estatutos de los daguers de Barcelona, de 1512, no consentían, bajo pena de veinticinco ducados, el acaparamiento que podía conseguir un maestro que por su cuenta hiciese trabajar a otros maestros poniendo en la obra realizada el punzón del maestro empresario, pues con ello éste usurpaba el derecho a la notoriedad y buena fama de los demás maestros, fundamento de la propiedad artística ${ }^{82}$.

Con el correr de los años, los oficios se fueron especializando y desmembrando del gremio a que pertenecían, y éste es el caso de «los cuchilleros de Barcelona, conocidos con el nombre de dagueros, que estaban agregados como oficio de fabricantes en hierro á los cerrajeros del barrio de Regomí. Pero á 12 de mayo de 1512 el Concejo Municipal dividió estos dos oficios á instancia de los mismos cuchilleros, atendida la notable diferencia que hay entre las dos profesiones, y quanto conviene para la perfección de las artes el subdividir alguna vez los ramos de la industria; y les dio facultad para formar su cofradía baxo la invocación de San Eloy en la Iglesia Parroquial de San Justo y Pastor de aquella Capital. Aprobaronseles ciertos cuerpos de estatutos con los que se han gobernado hasta hoy; y se reducen á lo siguiente. Que se elijan todos los años tres Prohombres para el régimen del gremio: que estos tengan facultad por sí de juntar los vocales siempre que lo juzguen conveniente; que no puedan resolver de su propia autoridad caso alguno árduo ó extraordinario, y sí sólo los comunes, según la práctica del gremio y el tenor de sus ordenanzas; que los que hayan sido una vez Prohombres ú oficiales del gremio, no pueden volver á obtener cargo alguno sin haber mediado dos años; que cada individuo pague anualmente quatro sueldos y qua-

so Archivo Municipal de Valencia, Manual de Consells y Establiments, núm. 43 (41 A), fol. 28; según José María Ibarra y Folgado, op. cit., pág. 34.

${ }_{81}$ Terónimo López de Ayala y Alvarez de Toledo, Toledo en el siglo XVI después del vencimiento de las comunidades, Madrid, 1901, pág. 139, nota 134.

$\$ 2$ Estanislao Segarra, Los gremios, Barcelona, 1911, pág. 93. 
tro dineros que se han de exigir por semanas para los gastos de la fiesta del Santo tutelar; que ningún maestro pueda prestar su nombre á otro só pena de veinte y cinco ducados; que para la buena harmonía de los gremiales, y perfección del oficio, en la casa de las juntas se guarde un libro en que estén estampadas las marcas con que cada individuo señala las piezas de su fábrica; que a fin de evitar la proporción con que los demás fabricantes de fuera de Barcelona podían introducir fraudulentamente en ella artefactos con marcas contrahechas, se rompan aquellos que se encuentren con semejantes engaños; que para que el público y el extrangero queden bien servidos en el surtimiento de piezas de fábrica baicelonesa, debían los maestros traher toda la obra concluída á la casa del gremio para ser allí examinada antes de poderla vender, con la ley de que no hallándose de buena calidad se rompa á presencia de los Prohombres; que los aspirantes á la maestría debían haber hecho quatro años de aprendizage, y dos de oficialía en casa de maestro aprobado con obrador propio y corriente, sujetándose á pagar por la recepción veinte y quatro ducados» ${ }^{83}$.

1556 El 15 de julio de 1556 fueron confirmadas en Nueva España las primeras ordenanzas de espaderos por don Luis de Velasco, y en ellas, al hablar del examen que debían superar los aspirantes, se decía textualmente: «Que el examen ha de ser de una vaina de terciopelo con correas y puño de seda; otra de un montante, de un puñal, otra de cuchillo con puño vayo, y de una espada de una mano; y ha de amolar una espada, azicalarla y bruñirla; y una vaina con cuchillos de lustre, y un puño entorchado, todo lo haga delante de los veedores, y ha de pagar el examinando a los veedores dos pesos» ${ }^{34}$.

1567 Don Pedro Sánchez de la Torre, en nombre de todos los espaderos de la ciudad de Toledo, el 9 de mayo de 1567, eleva al rey Felipe II un escrito diciendo que la ciudad ha hecho unas ordenanzas del oficio de espaderos que les son muy útiles y provechosas. El rey les contesta proponiéndoles que se junten en consejo abierto los regidores, jurados y oficiales de la ciudad, con cualquier otra persona que desee participar, para que dialoguen («platiqueis») acerca de estas ordenanzas, y una vez discutidas, conclu-

"3 Antonio Capmany y de Montpalau, Memorias bistóricas sobre la marina, comercio y arles de la antigua ciudad de Barcelona, tomo I, Madrid, 1779, parte tercera, cap. IV, pág. 66.

"Francisco Santiago Cruz, Las arles y los gremios en la Nueva España, Ed. Jus, S. A., Méjico, 1960. 
siones y contradicciones sean mandadas cerradas y selladas al rey para su confirmación ${ }^{25}$.

Se llama después a Juan de Roa, Francisco Hernández y Alfonso Sánchez, famosos maestros, quienes, tras haber jurado, son interrogados con el cuestionario de rigor sobre si conocen dichas ordenanzas. Contestan que las conocen, que saben que son útiles y provechosas, y por ello confirman que a nadie harán daño; por el contrario, serán de gran utilidid, y añaden que las penas previstas son justas y no excesivas, firmaildo todo ello bajo juramento. Visto este requisito, el rey las cronfirma el año de $1572 \%$

Esta mención a lias ordınanzas de los espaderos se debe al hecho de que en aquellos años, ell esa ciudad, el gremio de cuchilleros no había adcjuirido todavía, al parecer, auténtica carta de naturaleza; ese status se lograría más adelante con la ratificación de las ordenanzas en $1689^{87}$. Prucba de lo expuesto es que al referirse aquellas ordenanzas de espaleros a las pruebas que habían de superar los futuros maestros, el artículo séptimo dispone que el examinando «sepa guarnecer vil cuchillo cazudo de monte, con tres cuchillos, y vn martillo, $y$ lo demas que perteneciere. $Y$ en la tal piez! vaya puño de rederilía y fluecos».

1591 A los aspirantes a maestros del gremio de cuchilleros de Zaragoza, según las nuevas ordenarzas de 1591 , se les exigía la fabricación de «una cuchillera con dos cuchillas grandes, una roma y otra de punta caída, y estas piezas debian ser forjadas de baquete, esto es calzadas de cazo, y filo de acero, y à mas otras tres piezas; que eran un tenedor, un cuchillo mediano de trinchar, y otro mas pequeño. Mas: una cax? de fraile con tixeras de gozne, dos cuchillas tingladas con nutias de latón, y cahacados de trasin, con un cortaplumas de lo misiño: una lanceta para cerrar cartas, que salga del mismo cuchillo, y dos pares de tixeras unas de escritorio, y otras de barbero" "

"Espriranza Pjidraza, op. cil., pág. 159.

: Ibidem, pág. 159.

s Axtonio Martín Gamero, en las Ordenanzas para el buen régimen y gobierno de la miry noble, muy leal e imperial cindad de Toledo, Discurso preliminar, página XIV, nota 1, dice: «Guárdanse en nuestro archivo las Ordenanzas de los cuchilleros de $1689 \ldots$... Pero según nos confirma la secretaria de la Real Academia de Bellas Artes y Ciencias Históricas de Toledo y directora del Archivo del Ayuntamiento de esta ciudad el 7 de enero de 1985, lamentablemente estas ordenanzas no aparecen, temiéndose lo peor.

s: Ignacio JoRdán de Asso y del Río, op. cit., pág. 130. 
1598 En Madrid, los cuchilleros consiguen que sus ordenanzas gremiales sean aprobadas en $1598^{89}$.

Para concluir el siglo XVI, se puede afirmar que durante esta centuria los gremios de cuchilleros están, en general, plenamente consolidados en nuestra Patria y que las herramientas de trabajo, los utensilios domésticos y las armas blancas cortas que salen de sus talleres artesanos gozan de una calidad técnica y de una belleza que les dará justa fama y prestigio internacional. Así, incluso en una pequeña ciudad del norte de Cataluña como era Solsona, «els ganivets produits pel daguers solsonins eren força apreciats" ${ }^{20}$.

1602 En 1602, los integrantes del gremio de cuchilleros de Teruel presentan una petición sobre franquicias a los jurados de esta ciudad; los muchos firmantes que aparecen citados en el documento hacen pensar a Jordán de Asso ${ }^{\text {g1 }}$ lo numeroso que era este gremio a principios del siglo XVII.

1606 José López, cuchillero de Madrid, formula una petición en forma a fin de que le sean concedidos cuatro meses de plazo para examinarse, dado que ahora se encuentra muy pobre, enfermo y ausente de la corte ${ }^{2}$.

1615 Diego de Sosa, cuchillero del rey nuestro señor, el 10 de agosto de 1615 , solicita autorización para adquirir determinados materiales que precisa para el ejercicio de su oficio ${ }^{93}$.

1622 El rey Felipe III, el 3 de octubre de 1622, a petición del corregidor don Diego Hurtado de Mendoza, confirma las Ordenanzas de Toledo de 1572. Más adelante, en 1776, serán reformadas de nuevo ${ }^{\text {M. }}$.

1628 La pragmática de 13 de septiembre de 1628 establece la «tasa de los precios a que se han de vender las mercaderías y otras cosas de que no se hizo mención en la primera tasa, y reformación que ahora se ha hecho por los señores del Consejo en algunos precios que se pusieron en ella. Así:

"7 Antonio Rumeu de Armas, Historia de la previsión social en España. Cofradias, gremios, beimandades y montepios, Ed. Revista de Derecho Privado, Madrid, 1944 , pág. 185.

"M. Riu, Geografía de Catalunya, en «El Solsonès» (Barcelona, 1964), pág. 508; según Ramón Pianes y Albets, op. cit., pág. 94.

"I IGNaCio Jordín de Asso y del Río, op. cit., pág. 158.

"2 A. H. N., Sala de Alcaldes, año 1606, tomo 1, fol. 450.

${ }^{93}$ A. H. N., Sala de Alcaldes, año 1617, fol. 29.

${ }^{9}$ Esperanza Pedraza, op. cit., pág. 162. 
Cuchillos para mesa, finos, grandes .......... I real

Cuchillos para mesa, finos, medianos ........ 1 cuarto de real

Cuchillos para escribanía .................... 20 mrs.

Cuchillos ordinarios, dos, con su caja ........ 1 real y cuartillo

Tijeras redondas, finas, de despabilar ........ 1 real y medio

Tijeras de escribanía ........................ 1 real

Navajas ordinarias ......................... 20 mrs.

Navajas finas, de todas suertes ............... 1 real y medio

Navajas de barbero, grandes ................. 1 real y medio

Las pequeñas ................................ 1 real

Tijeras finas de barbero, grandes ............ 3 reales

Tijeras finas de barbero, chicas .............. 2 reales ${ }^{*}{ }^{*}$.

1632 En 1632 tuvo lugar la «Recopilación de las Ordenanzals de la muy noble y muy leal cibdad de Sevilla: de todas las leyes y ordenamientos antiguos y modernos; cartas y prouisiones Reales, para la buena gouernación del bien publico y pacifico regimiento de Sevilla y su tierra. Fecha por mandado de los muy altos y muy poderosos Catholicos Reyes y señores, don Fernando y doña Isabel, de gloriusa memoria, y por su Real prouision», y entre los muchos estatutos que en esta recopilación se incluye está el «de los Cochilleros» ${ }^{*}$, que tenía una recia e intensa tradición, como lo confirma el hecho de que en la última disposición de esta ordenanza se diga que «en este oficio de cuchillero no ha de auer Alcaldes, porque en quanto a este se revoco por el Cabildo y Regimiento de Seuilla, en seys dias del mes de setiembre de mill y quinientos y veyute y cinco años».

1668 Las ordenanzas de cuchilleros de la ciudad de Teruel datan de 1668, y al parecer sus artífices fueron famosos por los cuchillos, navajas y puñales que elaboraron ${ }^{7}$.

1680 Según la «Memoria de los precios a que han de vender los Maestros Cuchilleros en esta Corte», los mismos quedaban fijados en la siguiente relación:

Un par de tixeras grandes de Sastre .......... 19 reales

Un par de tixeras medianas de Sastre ........ 14 reales

Un par de tixeras pequeñas de Sastre ........ 10 reales

"Sanmejo V1ñas y Mey, Cuadro económico-social de la España de 1627-1628. Pragnática sobre lasas de las mercaderías y mantenimientos, jornales y salarios, en "Anuario de Historia Económica y Sucial», año I, núm. I (enero-diciembre 1968), párs. 745 y 757 .

C. Cfr. Apéndice.

"I Ignacio Jordín de Asso y del Río, op. cil., pág. 158. 
Un adereço de escriuanias, que son dos cuchillos y vnas tixeras .......................... Un adereço de escriuanias pequeño ............ Un adereço de escriuanias mayor ............... Un cuchillo de fraile tinglado ................ Un cuchillo de plumas, de cabo de cuerno ... 2 reales y medio Un cuchillo de plumas, de cabo de hierro ..... 2 reales

Un puñal de monte, de vna tercia, con cuchillo pequeño, lima ralpa y aguja .............. 20 reales

Dichos cuchillos de monte, de media vara ... 35 reales

Un cuchillo de mesa, con chapeta arriba, fino. 3 reales y medio Dicho cuchillo fino, sin chapeta .............. 2 reales y medio Un cuchillo de trinchar ...................... 5 reales

Unas tixeras de Platero grandes ............ 21 reales

Unas tixeras de Guanteros y Zapateros ...... 19 reales Unas tixeras grandes de Iardinero, de dos ma-

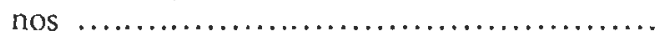

Unas tixeras medianas de Iardinero, de una mano ................................... 5 reales

Un podon de mano ......................... 5 reales

Un podon de peto, de espiga .............. 7 reales y medio Tranchetes de Zapatero de viejo ............. 5 reales

Tranchetes de Zapatero de obra prima ..... 5 reales Cada hoja de daga de dos tercias ............ 10 reales Puñal de cinta con cuchillo y bayna ........... 15 reales ${ }^{\text {s }}$.

Resulta curioso observar este intervencionismo cstatal al establecer unos precios invariables hasta para artículos de uso corriente y menor valor. Ello se produjo por abusos cometidos en todos los órdenes - pues la medida no se limitó al ámbito de la cuchillería, sino que contempló todo el comercio en general-, y con ello se pretendía conseguir una estabilidad económica, una cierta confianza en el consumidor y la desaparición de la competencia dentro del mismo gremio.

1689 El día 29 de abril de 1689, la Alcaldía de Casa y Corte estableció ciertas medidas contra la introducción de armas blancas falsamente fabricadas al decir: «Por cuanto se ha experimentado que de las ciudades de Robledo, Guadalajara, Mora, Alcalá y otras de Castilla se trae a esta Corte géneros tocantes al Gremio de cuchi-

9* A.H. N., Sala de Alcaldes, año 1680, fols, 315 y 362; Cédula Real en que su Magestad manda se observe y guarde la moderación de alquileres de casas y precios de todos généros comerciables..., pág. 46. 
lleros como son puñales, cuchillos, texeras de mala calidad y falsamente fabricadas contra ordenanza en perjuicio de las personas que las compran por parecerles ser obra de Puerta Zerrada en que son engañados... mandamos se publique en esta Corte que de aquí en adelante todas las personas que introduxeren en ella herramientas destas calidad; antes de venderlas o destruirlas sea de su obligación acudir a los veedores y examinadores del Gremio de cuchilleros de esta Corte para que vean y reconozcan las dichas herramientas y si están o no fabricadas conforme a la ordenanza $y$ si no lo estuviese la persona que las tuviere las vuelva a sacar sin poderlas vender en la Corte por mayor ni por menor a otra ninguna. Pena de cien ducados y la obra perdida... ${ }^{99}$.

1689 Tal y como se expuso en los párrafos finales del capítulo I, la general decadencia de los gremios a fines del siglo xvis es manifiesta; pero ello no obstante, algunos de ellos, como ocurrió en Toledo con el de cuchilleros, piden y obtienen la aprobación de sus ordenanzas en $1689^{\circ}$, que, según San Román ${ }^{101}$, éstas no eran otras que las de la ciudad de Sevilla de $1525^{102}$.

1696 Al hablar del aspecto económico de los gremios ya se expuso la obligación existente de que cuando se traía a la ciudad materias primas o elementos imprescindibles para la fabricación de los cuchillos y navajas había la obligación de dar cuenta a los veedores para que éstos procedieran al reparto entre los agremiados de forma equitativa. Esta norma de procedimiento se tuvo presente cuando Domingo González y Thomas Sánchez, el 3 de mayo de 1696, trajeron a Madrid veintiséis piedras de amolar ${ }^{103}$.

Se puede concluir las referencias documentales de este siglo xvix afirmando, a modo de resumen, que la vida corporativa del gremio de cuchilleros en general continúa su auge y esplendor, aunque en algunas poblaciones se empiece a detectar síntomas de crisis y estancamiento de su funcionamiento y evolución económica. Prueba del vigor del gremio de cuchilleros a lo largo de esta centuria es la autorización por el municipio y la corona de algunas ordenanzas, la reforma, recopilación y confirmación de otras y la constante preocupación del gremio por la pureza de las obras que

9. A.H. N., Sala de Alcaldes, año 1689, fol, 49.

100 Cfr. nota 87.

in Francisco de Borja San Román y Ferníndez, Los gremios toledanos en el siglo XVII, Publicaciones de la Delegación Provincial de Educación Nacional de F. E. T. y de las J.O.N.S., Toledo, 1970, pág. 19.

${ }^{102}$ Cfr. final de lo expuesto sobre las Ordenanzas de Sevilla de 1632.

${ }^{1113}$ A. H. N., Sala de Alcaldes, año 1696 , fols. 52 y 53. 
fabricaba, adoptando toda clase de rigurosas medidas disciplinarias contra cualquier clase de acción que pudiera perjudicar el buen nombre y la justa fama de la artesanía local de los cuchillos, las navajas, los puñales y las tijeras, que era, en gran medida, el sustento de sus habitantes y la gloria de su industria.

1701 La ciudad de Toledo había perdido a finales del siglo xvIr gran parte de su esplendor; el traslado de la corte a Madrid, la depresión general de la economía española, el descenso demográfico, la expulsión de los moriscos y la importación de armas blancas, principalmente, motivaron que el gremio de cuchilleros quedara reducido a su mínima expresión, como lo prueba el hecho de que en el censo realizado con motivo del reclutamiento para la guerra de Sucesión solamente quedaran en Toledo cuatro maestros cuchilleros y dos aprendices ${ }^{104}$.

1713 La conducta de los veedores y examinadores del gremio de cuchilleros no siempre fue ejemplar, pues en algunas ocasiones eran negligentes con sus quehaceres corporativos y evadían sus obligaciones de examinar, como un tal Juan Tejero afirma que sucedió con su representado, el oficial cuchillero José Rallón, que tuvo que recurrir a la autoridad municipal para que le nombraran otros veedores, quienes le examinaron y encontraron capacitado, dándole, el 17 de marzo de 1713, carta de examen, según la costumbre 105 .

1718 El censo profesional realizado en Solsona el año 1718 demuestra que el arl de foc - que en esta ciudad y época era prácticamente lo mismo que decir el arte de la cuchillería - ocupaba el 6,68 por 100 de la población, lo que suponía una parte importante de la misma, dado que entre «payeses», «pobres e inválidos», «otros» $y$ «no consta» se alcanzaba el 59 por 100 de los solsonenses en ese año ${ }^{106}$.

1736 No muy desarrollado debió de estar el gremio de cuchilleros en Cartagena durante el primer tercio del siglo xvirr, cuando las ordenanzas de noviembre de 1736 recogen de forma unitaria los oficios de cerrajeros, herreros, escopeteros y cuchilleros. Su breve contenido se limita a fijar las cantidades que los examinandos debían pagar, haciendo distinción en la cuantía según se fuera o no hijo de maestro y natural de la ciudad o forastero, así como el destino de estos fondos. Por otra parte, se dejaba la puerta abierta a la posibilidad de independizarse si crecía suficientemente el nú-

104 Espreranza Pedraza, op. cit, pág. 124.

105 A. H. N., Sala de Alcaldes, año 1713, fol. 73.

10 Ramón Planes y Alebets, op. cit., pág. 95. 
mero de miembros. Se establecía la obligación de retirar los bancos y mesas de trabajo en el caso de que la ciudad formada pasase por las calles donde estos gremios estaban establecidos, como señal y demostración de respeto, bajo pena de 600 maravedíes. Se manda «que el maestro de dichos oficios que no asistiese en las ocasiones de salir el Gremio con su pendón a acompañarle en la forma que los demás, sea penado en cuatro reales de vellón y en dos reales el oficial que faltare a la propia asistencia, los que se aplicarán a el arca de los fondos, entendiéndose cuando no teniendo excusa o arbitrio de los maestros veedores de cada oficio». Finalmente, añadía «que siempre que cualquiera pieza u obra de dichos maestros se hallare falsa, viciada o en otra forma defectuosa según los veedores, deben recurrir al maestro que la ha hecho dando a la parte otra pieza de bondad y calidad a su propia costa», medida esta muy representativa del esmero que el gremio ponía siempre en la perfección de la obra manufacturada ${ }^{107}$.

1750 El catastro del marqués de la Ensenada - base fundamental para el establecimiento de la «única contribución»-, que abarcaba, como es sabido, las veintidós provincias de Castilla y León, y por cllo quedaban fuera del informe Vascongadas, Cataluña, Valencia y Aragón, tiene especialísimo interés para este estudio, pues en él se observa, en primer lugar, que en la mitad de las provincias -Avila, Burgos, Ciudad Real, Córdoba, Cuenca, Granada, Madrid (sin el casco de la villa), Salamanca, Sevilla, Soria y Zamorael gremio de cuchilleros no se menciona en absoluto, lo cual es un hecho a constatar dada la importancia de esta artesanía en alguna de las ciudades contempladas, de manera especial en Sevilla ${ }^{103}$. En segundo lugar, en el cuadro que se presenta a continuación, que recoge las provincias donde existían cuchilleros, se observa: * Que el gremio más citado pot provincias de entre los herteros, cerrajeros, armeros y cuchilleros con los que en la mayoría de las provincias aparece citado es el de cuchilleros, que representa el 40 por 100 de éstos.

$*$ Que si este 40 por 100 se aplica a los totales obtenidos, observamos que al gremio de cuchilleros corresponden en estos años y provincias: 2.686 trabajadores, de los que 1.845 eran maestros; 596 oficiales, y 244 aprendices.

* Que las provincias (o regiones) que contaban con más cuchille-

107 Eduardo Cañabate Navarro, op. cit, pág. 25.

${ }^{105}$ Para lo que se refiere al catastro de Ensenada, se ha seguido a Antonio MA'Illla Tascón, op. cit., passim, y El primer catastro de la villa de Madrid, en «Revista de Archivos, Bibliolecas y Museos», tomo IXIX, vol. 2 (1961), págs. 464-525. 
ros eran León (2.106), Galicia (1.997) y Extremadura (985), y las que menos, Valladolid (18), Toro (15) ${ }^{10 \%}$, Toledo (4) y Guadalajara (1).

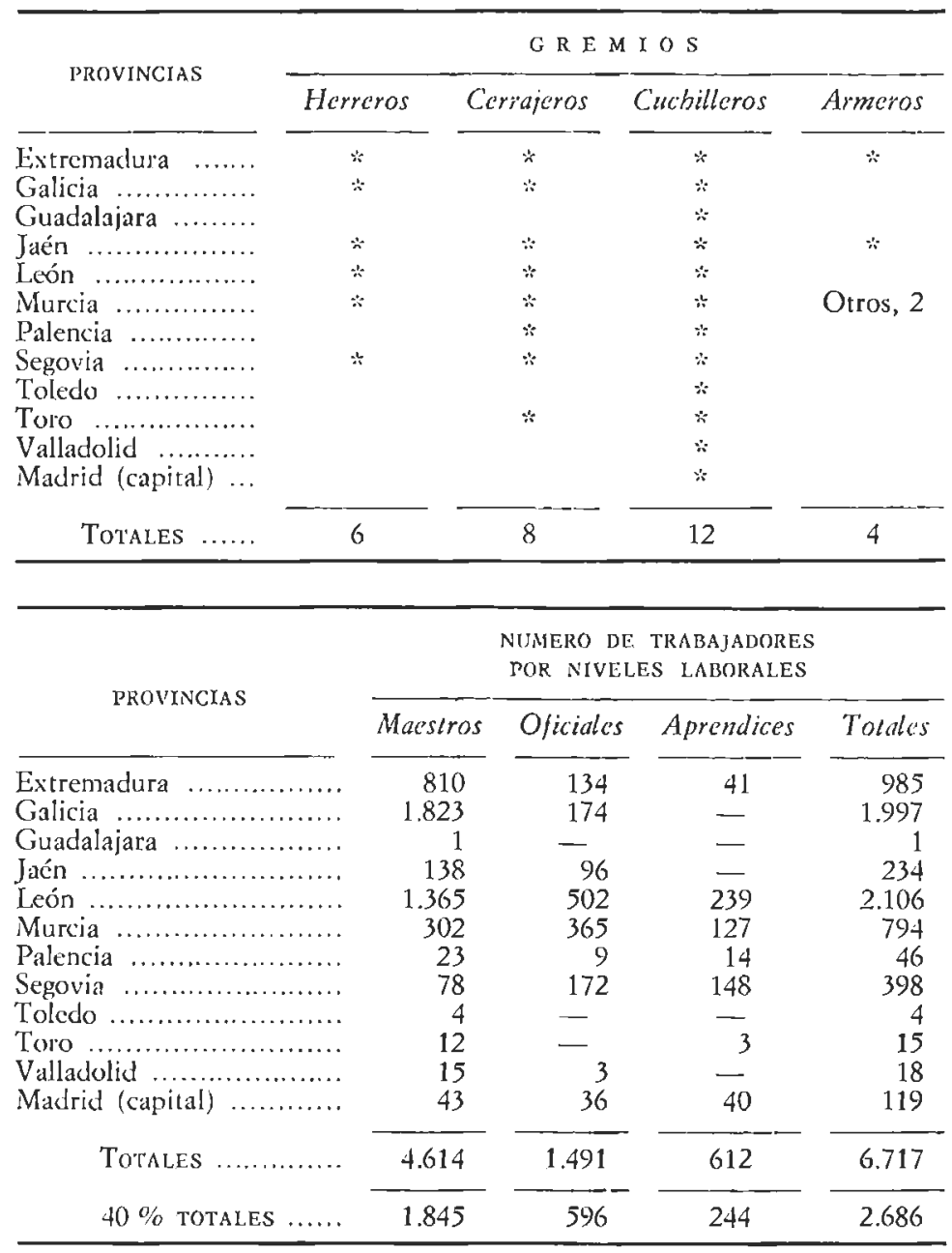

10. La provincia de Toro fue una demarcación administrativa un tanto artificial, que duró unos setenta años, y que discurría en forma de lengua desde Santander al norte de Extremadura, teniendo como razón de ser el evitar el pago de puertos en la transhumancia de los ganados. 
En kercer lugar, en el cuadro siguiente se recogen, en reales de vellón, las cantidades totales, por provincias y niveles laborales, a las que ascendían los jornales anuales de los trabajadores del gremio de cerrajeros, herreros, armeros y cuchilleros en aquellas provincias que contaban con estos últimos durante los años 1750 a 1756.

\begin{tabular}{|c|c|c|c|c|}
\hline PROVINCIAS & Macstros & Oficiales & Aprendices & Totales \\
\hline Extremadura & 691.200 & 68.220 & 10.440 & 769.860 \\
\hline Galicia & 1.226 .700 & 64.530 & - & 1.291 .230 \\
\hline Guactalajara & 540 & - & - & 540 \\
\hline Jaén …........ & 116.280 & 47.880 & -- & 164.160 \\
\hline León & 867.060 & 204.750 & 60.480 & 1.132 .290 \\
\hline Murcia & 376.830 & 273.510 & 40.050 & 690.390 \\
\hline Palencia ............... & 15.660 & 3.780 & 3.150 & 22.590 \\
\hline Segovia............. & 81.000 & 128.340 & 75.105 & 284.445 \\
\hline Toledo & 4.320 & - & - & 4.320 \\
\hline Toro ... & 10.620 & - & 900 & 11.520 \\
\hline Valladolid ............. & 11.430 & 1.080 & - & 12.510 \\
\hline Madlrid ............... & 5.858 & - & 42.600 & 48.458 \\
\hline To'TALES ......... & 3.407 .498 & 792.090 & 232.725 & 4.432 .313 \\
\hline $40 \%$ TOTALES.. & 1.362 .999 & 316.836 & 93.090 & 1.772 .925 \\
\hline
\end{tabular}

1760 Carlos III, deseoso de restaurar la fabricación de armas blancas en España, pidió información sobre el estado de esta industria en Toledo enviando un cuestionario, que fue contestado por Francisco Santiago Palomares el 17 de octubre de 1760, y que motivó una reunión en la que se discutió ampliamente el tema en presencia del intendente general de Hacienda y Guerra, que dio lugar a un informe del coronel Luis de Urbina el 22 de ese mismo mes, en el que, entre otras cosas, confirma la existencia de cuchilleros - no de espaderos - en la imperial ciudad, diciendo: «Se me asegura que estos cuchilleros dan buen temple a sus cuchillos, navajas y tijeras, y entre ellos los llamados Felipe Luis, Juan Muñoz, Juan Antonio e Ignacio Fernández... que conservan algunos de los instrumentos que usaban los antiguos... que han conservado el secreto de padres a hijos, que saben el agua de que se ha de usar y en que tiempos...»" ${ }^{110}$.

La Real Fábrica de Espadas de Corte, que así se llamó primero, empezó a funcionar en 1761 , pero fue el 23 de junio de 1781

110 Espreranza Pedraza, op. cit., pág. 172. 
cuando los operarios comenzaron a trabajar en la Fábrica Nacional de Armas, sita en su actual emplazamiento.

1767 Según una relación catastral realizada en 1767, existían en Solsona en este año dieciséis maestros cuchilleros, que concretamente eran: Joan Busquets, Francesc Fábrega, Josep Figueres, Josep Isanta, Agustí Capdevila, Francesc Closa, Anton Closa, Francesc Elies, Salvador Canal, Pere Márlir Blanch, Rafael Rodamilans, Miquel Montells, Josep Robert, Francesc Isanta, Francesc Llord (el viejo) y Francesc Llord (el mozo). En los años siguientes, este gremio se desarrolló muy notablemente, contabilizándose hasta veinticuatro talleres, con un númcro de «mancebos» cada uno que oscilaba entre cuatro y diez. Sus navajas, cuchillos y puñales eran enviados a toda Cataluña, a Castilla e incluso a Indias ${ }^{111}$.

1770 Es en 1770 cuando tiene lugar la presentación al Consejo de Castilla, para su aprobación, de los estatutos del art de foc de Solsona, entre los que se encuentra el del gremio de cuchilleros ${ }^{112}$, en el que, entre otras cuestiones, se establece:

* Que el que desee ser maestro deberá haber practicado en este oficio durante cuatro años, presentando además una certificación jurada del maestro con el que se ha adiestrado durante esos cuatro años.

$*$ Que cuando haya que proceder a examinar a un aspirante hidbrá que elegir a dos maestros, que deberán asistir «quando y en la ocasión se fabricaran u trabajaran dichas cosas», abonándoseles por el examinando un salario suficiente cuyo importe será fijado por los priores del gremio.

$\because$ Que si los aspirantes fuesen hijos de maestros dagueros de la ciudad solamente se les hará fabricar «un cortaplumas u otras piexas a aquellos bien vistas, a excepción, empero, del hijo primogénito de tales maestros, que únicamente le harán o deverán hazer fabricar un cortaplumas».

1771 En el informe redactado por Juan Cervera, titulado Zaragoza. Estaclo de las cofradias de la ciudad de Zaragoza y pueblos de su partido, de 1771, se dice que en la iglesia del Temple de la Religión de Caballeros de Malta figura el gremio de puñaleros, cuyo titular es San Martín, que tiene ordinaciones y que celebra una misa cantada, una fiesta solemne y trece sufragios ${ }^{113}$.

"11 Archivo de Protocolos de Solsona, Instrumenta per Dominicum Agnilor nota;ium publicum Coelsonde uti substitutum discreti Thomae Llorens, recogido por RAmón Planes i Albets, op. cit., págs. 100 y 102.

112 C.fr. Apéndice.

113 A. H. N., Consejos, Jeg. 7.105, exp. 64, núm. 132. 
1772 El 30 de septiembre de 1772 es el día en que Francisco Santiago Palomares da a la luz pública su Noticia de la Fábrica de espadas de Toledo que por tantos siglos existió basta fines del siglo XVII en que acabó y del método que tenian aquellos artifices armeros para forjarlas y templarlas, aceros que usaban, y otras particularidades que las bicieron tan famosas en todo el Mundo como apetecidas al presente y de la que por el Rey N. S. que Dios guarde se estableció en esta Ciudad año de 1760 por Francisco de Santiago Palomares escribano mayor de primeros remates de rentas decimales de Toledo y su Arzobispado ${ }^{114}$. Se cita aquí esta obra y autor por dos razones fundamentales: la primera porque aunque en principio parece habría de referirse exclusivamente a la espadería, la realidad es muy otra, pues de los noventa y nueve punzones que aparecen dibujados e identificados muchos de ellos se encuentran acuñados en bellas hojas de cuchillos, puñales y navajas, lo que indica que estos «espaderos» se dedicaban igualmente a la fabricación de armas blancas cortas y utensilios domésticos de cierta categoría, y la segunda porque las investigaciones de Santiago Palomares y lo que dejó escrito ha sido la fuente en la que ha bebido la mayoría de los estudiosos posteriores de esta apasionante rama de la historia de España.

1775 Poco vigor debió de tener la vida gremial de los cuchilleros toledanos en el último tercio del siglo xviru cuando ellos, que tenían ordenanzas desde 1689 , solicitaron otras nuevas en 1775 , como lo atestigua Larruga ${ }^{115}$ en $1791-\mathrm{y}$, por tanto, habiendo tenido ocasión de comprobarlo personalmente- y lo confirma Pérez Bueno ${ }^{116}$, siendo lo peor, según este último, que la autoridad contestó a su pretensión diciendo «que ponían reparos, porque los que solicitaban las Ordenanzas no tenían los conocimientos que convienen para merecerlas».

1781 Era tradicional en la vida gremial española que los extranjeros encontraran ciertas dificultades a la hora de instalarse y ejercer su profesión en nuestro país. Como testimonio de ello se recoge a continuación un caso ocurrido en San Sebastián en el que se tiene que recurrir a los tribunales de justicia para que el extranjero, en este caso francés, goce de los derechos profesionales que la ley española le reconocía.

114 Cfr. Apéndice.

nis Eugenio Larruga, Memorias politicas y económicas, sobre los frulos, comercio, fábricas y minas de España, tomo X, Madrid, 1791, pág. 102.

${ }_{116}$ LuIs Pérez Bueno, Indice de oficios arlesanos, Obra Sindical de Artesanía, Delegación Nacional de Sindicatos, Madrid, 1950, cap. «Arte del hierro y metalcs y similares». 
«Don Pedro Flores Manzano, del Concejo de S. M., su oidor en la Real Chancillería de Valladolid, y Corregidor de esta Provincia. Hago saber a la Justicia de la ciudad de San Sebastián y a cualquier escribano de $S$. $M$., que ante mi se presentó una petición cuyo tenor y de un auto es como sigue.

»Gerónimo de Cincunegui en nombre de Carlos Douset maestro cuchillero residente en la ciudad de San Sebastián, pero de nación francés, cuyo poder especial presento, acepto y juro, ante V. M. parezco por el recurso o queja que más haya lugar en derecho me presento, y hallándome como despojado de mi tienda y poder trabajar en ella, mediante los atropellados procedimientos de la Justicia, escribano y Ministro de dicha ciudad, digo que hace ocho días que el Alcalde de dicha ciudad por medio del Escribano y Alguacil intimó a mi parte con pena de prisión y otras, cerrase luego a punto la tienda y no trabajase en su oficio de cuchillería ni otro, con el pretexto que no estaba examinado conforme al Capítulo cuarto de las ordenanzas confirmadas de la Colradía de San Eloy... De estos autos consta que el año de setenta y dos cuando era recién venido mi parte a dicha ciudad, se presentó al mayordomo, que era entonces de dicha cofradía D. Juan Francisco de Cardaberaz, quien inmediatamente para ser examinado, mi parte, le encargó seis hojas de cuchillos, enviándole él mismo mangos de plata, y por cuanto en este intermedio experimentó la novedad extraña de que si no pagaba treinta y seis ducados de vellón había de cerrar la tienda, acudió en dicho año mi parte a este tribunal por el remedio en la misma conformidad que lo hace ahora, y con efecto interín se le informase al caballero Corregidor de lo ocurrido, se mandó no se le impidiese a dicha mi parte el uso de su oficio, en vista de esta providencia en estos nueve años ha estado mi parte con tienda abierta, usando su oficio, sin que se le haya puesto embarazo alguno hasta el presente lance, y sólo por esta posesión pacífica en que ha estado mi parte de usar su oficio en virtud del citado auto...

»Se manda que la Justicia de la Ciudad de San Sebastián ponga a Carlos Douset, maestro cuchillero residente en ella, en posesión y uso de su oficio y nadie le impida en el ejercicio de su arte... El Señor Corregidor de esta Provincia lo mandó en Audiencia de veinte y uno de Mayo de mil setecientos ochenta y uno...» ${ }^{117}$.

117 Archivo Provincial de Guipúzcoa, sec. 2. ${ }^{2}$, neg. 21, año 1781, leg. 84, recogido por Juan Garmendia Larrañaga, Gremios, oficios y cofradias en el País Vasco, Ed. Caja de Ahorros Provincial de Guípúzcoa, San Sebastián, 1979, pág. 190. 
En el Libro de Gobierno de 1781, concretamente el 26 de abril de este año, al hablar de las costas, hay una demostración más de la necesidad de abonar el ejercicio de determinadas funciones gremiales cuando se dice: "A Manuel de Castro y Juan Esteban de Marcos, Maestros veedores del gremio de cuchilleros, por los reconocimientos que hicieron, se consideran cuatro» ${ }^{\mathrm{tt}}$.

1788 La importante función de los veedores se pone de manifiesto en el siguiente documento, que dice así: "Oficio de los Directores Generales de Rentas remitiendo a la Sala tres navajas distintas... que llegaron a la Aduana a fin de que se declarasen si eran o no de las prohibidas. Trece de Febrero de 1788.» Tras el examen que bajo juramento hicicron los veedores del gremio de cuchilleros de Madrid, éstos manifestaron: "Que las tres referidas navajas son para el uso de los pastores y arrieros, que no son de las prohibidas por no hallarse en ellas golpe seguro, abugetilla, ni virola que se ande alrededor, lo que hace que no tengan firmeza alguna y que aunque se hallan con punta, son necesarias para el uso de los pastores y arrieros, lo cual declaran con arreglo a la pericia de su oficio e inteligencia que en ello tienen y conforme a la Real Pragmática de 26 de abril de 1761 y Bando publicado en 9 de Octubre de $1780{ }^{119}$.

Jorge Aragoneses ${ }^{120}$, en un breve trabajo publicado a propósito de unas bellas tijeras albacetenses de 1771 , cita una serie de maestros cuchilleros que parece interesante recoger aquí. Son los siguientes: de Albacetc, Pedro Díaz (autor de unas tijeras de 1733), Gutiérrez (años 1737 y 1751), Arcos (año 1746), Castellanos (año 1756) y Miguel León (año 1771), y de Lorca (Murcia), Martínez y José Serrano (año 1708).

Se puede concluir este siglo xviII observando cómo la vida gremial en España estaba en plena decadencia y el gremio de cuchilleros no tenía motivo alguno para ser una excepción. Hubo, como siempre sucede con el acontecer humano, atisbos de florecimiento en alguna población (Solsona y $A$ lbacete, hasta la mitad del siglo), pero ello no fue sino la excepción de una regla general irreversible; el catastro del marqués de la Ensenada lo muestra bien a las claras. Toledo, ciudad cumbre de la cuchillería, no es ni sombra de lo que fue. De Aragón y el Levante español no contamos con

11 A. H. N., Sala de Alcaldes, Consejos, Libro de Gobierno, año 1781, fol. 565. a 715 .

A. H. N., Sala de Alcaldes, Consejos, Libro de Gobierno, año 1788, fols. 707

120 Manuel Jorge Aragoneses, Contribución al inventario provincial de artes industriales, en «Monteagudo», núm. 25 (1959), pág. 7. 
datos documentales, lo que es cicrtamente significativo, pues de las épocas de auge y gloria siempre quedan obras o al menos vestigios. Todo parece conducir indefectiblemente hacia la extinción general del gremio de cuchilleros.

1823 El 21 de noviembre de 1823, el maestro cuchillero Benito Yévenes, por sí y por otro «que no save firmar», contestó al corregidor de la villa de Madrid diciendo que, en la actualidad, los maestros cuchilleros existentes son: Pedro Sevillano, Benito Yévenes, Juan Cafio, Juan Jeta, Balentín Rueda, Cristóbal Carrasco, Alfonso Rodríguez, Pedro de los Ríos, Inocencio Navarro, Juan Bautista Maseras, Pedro Pasqual Marcos y Juan García del Villar, advirtiéndole que de estos maestros algunos no tienen tienda abierta y otros, sin estar examinados, se titulan maestros y sí tienen tienda abierta ${ }^{121}$.

1827 Pedro Pasqual Marcos, Cristóbal Carrasco y Pedro de los Ríos, maestros cuchilleros de Madrid, se dirigen, el 3 de noviembre de 1827, al corregidor comunicándole que fueron nombrados veedores en 1824, y por haber transcurrido con creces los tres años que según las ordenanzas debían ejercer dicha función, solicitan ser relevados de este cargo, proponiendo se nombren otros tres de entre los que sugieren, que concretamente son: Valentín Viloria, Ramón Longa, Inocencio Navarro, Pedro Sevillano y Juan Bautista Maseras, todos ellos maestros de este gremio. El 6 de noviembre de 1827, el corregidor de Madrid escribe al alguacil mayor diciéndole: «Para proceder con el debido conocimiento y acierto a la elección de veedores del Gremio de Maestros cuchilleros, necesito que a la posible brevedad y con toda la reserva me informe U. cuanto le conste y pueda averiguar acerca de la conducta y circunstancias de los individuos que a continuación se expresan, así como de sus conocimientos y suficiencia, proponiendo los que crea más a propósito para el desempeño de estos cargos.»

Dos días más tarde, el alguacil mayor contesta informando que el primero, segundo y cuarto de los citados gozan «de buena conducta y son suficientes para el desempeño»; pero Inocencio Navarro y Juan Bautista Maseras fueron «milicianos constitucionales» — «adictos al ominoso sistema constitucional», se dice en otro párrafo-, aunque «capaces al desempeño si no les es obstáculo

121 Exrique Pastor Mateos, Archivo Municipal de Madrid, Catálogo de gremios, núms. 296-299; Archivo de Corregimiento, núm. 1-206-1. 
su conducta política» ${ }^{122}$. Como puede observarse, en estos años las tendencias ideológicas y actuaciones políticas contaban tanto como los conocimientos y experiencia profesionales a la hora de ser nombrado para un cargo corporativo.

Pedro Pasqual Marcos, el 24 de noviembre de 1827, informa al corregidor de Madrid sobre el estado del gremio de cuchilleros en esta ciudad, diciendo que éste «se halla en la mayor decadencia; que los maestros que lo componen son nueve, de éstos tres sin poder travajar por causas físicas, y los demás tienen muy poco que elavorar; y carezen de ordenanzas para su govierno» ${ }^{123}$.

1829 Otro caso de petición de sustitución en el cargo de veedor es el formulado por Valentín Viloria y Ramón Longa el 12 de octubre de 1829, en Madrid, en que por haber transcurrido el plazo para el que fueron nombrados sugieren se nombre a otros en su lugar. Hechas las averiguaciones de rigor sobre «la conducta moral y política y sus conocimientos en el oficio» tal y como se pide, se contestó informando sobre los nombres sugeridos ${ }^{124}$, con observaciones tan curiosas como las siguientes: «de inteligencia, pero vinoso», "constitucional», «de mucha embriaguez», "pero fue miliciano», «voluntario realista», «poca ciencia en su profesión», "fue miliciano, pero tiene inteligencia y prudencia», "sin suficiencia». Las calificaciones reseñadas son tan elocuentes, que no vale la pena mayor comentario; únicamente señalar que el beber en exceso, en aquellos años, no debía de juzgarse como demasiado grave, pues uno de los tres artesanos elegidos adolecía de este defecto, o más bien diríamos, con el sentir de la época, tenía esta costumbre ${ }^{125}$.

1831 Don Domingo María Barrafón y Viñals de Fox, corregidor de la villa de Madrid, «en uso de las facultades que S. M. (Dios le guarde) se ha servido concederme... para que nombre interinamente los Oficiales y Empleados que con arreglo a las Ordenanzas gremiales deban gobernar los mismos, y debiendo procederse a la

${ }^{122}$ Enrioue Pastor Mateos, Archivo Municipal de Madrid, Catálogo de gremios, núms. 296-299; Archivo de Corregimiento, núm. 1-48-1.

is Ibiskm.

${ }^{124}$ Juan García del Villar, Juan Geta, Pedro Pasqual Marcos, Cristóval Carrasco, Faustino Liviero (?), Fermín del Rey, Pedro de los Ríos, Alfonso Rodríguez, Juan Bautista Mascras, Nicolás García del Villar, Pablo Francisco Geta, Mariano Pascual Marco, Miguel de Castro, Inocencio Navarro, Juan Eloy Sevillano, Juan Julián Gómez, Benito Rubio de Iglesias, Pascual Sevilla, Antonio Vidal, Juan Santalla, Francisco Portales y Francisco Fernández.

${ }_{125}$ Enrigue Pastor Mateos, Archivo Municipal de Madrid, Catálogo de gremios, núms. 296-299; Archivo de Corregimiento, núm. 1-48-1. 
elección de Veedores y Examinadores del Gremio de cuchilleros en grueso y menudo de esta Corte, he venido en nombrar como por el presente nombro para Veedores y Examinadores del citado Gremio a Alfonso Rodriguez, Pedro Pascual Marcos y Pablo Geta, los que desempeñarán las funciones que les son anexas, y celebrarán las Juntas que prebienen sus Ordenanzas... y para que se les reconozca por tales entre los individuos de que se compone el referido Gremio, y desempeñen cuantas atribuciones les son anexas; les doy el presente título en Madrid a seis de Mayo de mil ochocientos treinta y uno» ${ }^{125}$.

\section{Bibliografía}

Alcocer y Martínez, Mariano: Fuentes para la bistoria de los gremios, Valladolid, 1921.

Alcocer y Martínez, Mariano: Los gremios de Valladolid, Valladolid, 1927.

Almela y Vives, Francisco: Documentos gremiales en el Archivo Municipal, Valencia, 1958.

Anés Alvarez, Gonzalo: Los oficios mecánicos y viles durante el siglo XVIII, en «Anales de Economía», núms. 5-8 (enero-diciembre 1970), págs. 51-58.

Arco, Ricardo del: Antiguos gremios de Huesca, Zaragoza, 1911.

Basanta de la Riva, Alfredo: Fuentes para la bistoria de los gremios, Valladolid, 1921.

Bases y Estatutos de los Gremios del Comercio, Industria, Artes, Oficios y Profesiones y del Sindicato de Producción y de Consumo en la Región de Valencia, Valencia, 1882.

Bofarrull y de Sartorio, Manuel de: Gremios y cofradias de lo antigua Corona de Aragón, tomo I, Barcelona, 1876; tomo II, Barcelona, 1910.

Bonnassie, Pierre: La organización del trabajo en Barcelona a fines del siglo XV. Universidad de Barcelona, Instituto de Historia Medieval (C. S. I. C.), Barcelona, 1975.

Campo y de Echeverria, Antonio del: Los gremios en España (Discurso), Madrid, 1904.

Canellas López, Angel: El reino de Aragón en el siglo XV (1410-79), en Historia de España, dirigida por Ramón Menéndez Pidal, vol. XV, 2." ed., Espasa-Calpe, S. A., Madrid, 1970.

${ }^{126}$ Enkrque Pastor Mateos, Archivo Municipal de Madrid, Catálogo de gremios, núms. 296-299; Archivo de Corregimiento, núm. 1-167-19. 
Canellas López, Angel: Zaragoza medieval (1162-1479), en Historia de Zaragoza, tomo I, edición del Excelentísimo Ayuntamiento de Zaragoza, 1976.

Cañabate Navarro, Eduardo: Ordenanzas de los gremios de Carlagena en el siglo XVIII, Academia de Alíonso X el Sabio, Murcia, 1962.

Capella Vinktínez: La industria en Madrid, 2 vols., Madrid, 1965-66.

Capella, Miguel, y Matrlla Tascón, Antonio: Los cinco gremios mayores de Madrid, Madrid, 1957.

Capmany, Aurelio: Lo que queda de los antiguos gremios de Barcelona, diez artículos en números separados de la revista «Barcelona Atracción» en los años treinta.

Capmany y de Montpalau, Antonio: Memorias bistóricas sobre la marina, comercio y artes de lo aniigua ciudad de Barcelona, Madrid, 1779.

Carrancia y Trujallo, Raúl: Las ordenanzas de gremios de Nueva España, separata de la revista «Crisol», México, 1932.

Carrera Pujal, Jaime: Aspectos de la vida gremial barcelonesa en los siglos XVIII y XIX, en Estudios de la bisioria social de España, Instituto Balmes de Sociología (C.S. I. C.), Madrid, 1949, páginas 525-552.

Cruilles y SAgarra, Manuel: Los gremios de Valencia, Valencia, 1883. Cruz, Francisco Santiago: Las arles y los gremios en la Nueva España, Editorial Jus, S. A., México, 1960.

Domínguez OrTiz, Antonio: La sociedad española en el siglo XVIII, Instituto Balmes de Sociología, Departamento de Historia Social (C. S. I. C.), Madrid, 1955.

Ferrón Salvador, Vicente: Capillas y casas gremiales de la ciadad de Valencia, Valencia, 1922.

Frgueras Pacireco, Francisco: Los antiguos gremios de la ciuded de Alicante, Instituto de Estudios Álicantinos, Diputación Provincial de Alicante, 1958.

Fon'r, José María: Diccionario de bistoria de España, tomo II, 2." ed., Revista de Occidente, Madrid, 1968, págs. 248-251.

Fornies Casals, José Francisco: La Real Sociedad Económica Aragonesa de Amigos del País (Tesis), Confederación Española de Cajas de Ahorros, Madrid, 1978.

FIneITAG, Robert: La protección real de los gremios en el siglo XIV y los tintorevos de Perpiñán (Separata), tomo II, vol. 2, VIII Congreso de Historia de la Corona de Aragón, Valencia, 1970.

García Abellán, Juan: Organización de los gremios en la Murcia del siglo XVIII y recopilación de ordenanzas, Academia Alfonso $\mathrm{X}$ el Sabio, Murcia, 1976. 
García Valdeavellano, Luis: Curso de historia de las instituciones españolas, 5." ed., Ed. Revista de Occidente, Madrid, 1973.

Garmenda Larrañaga, Juan: Gremios, oficios y cofradias en el País Vasco, Caja de Ahorros Provincial de Guipúzcoa (Col. «Documento», núm. 24), 1979.

Gestoso y Pérez, José: Ensayo de un diccionario de los arlífices que florecieron en esta ciudad de Sevilla desde los siglos XIII al XVIII, 3 vols., Sevilla, 1899.

Gimeno Michavila, Vicente: Los antiguos gremios de Castellón, Castellón, 1933.

GonzÁl.ez, Hilario: Fábrica de armas blancas de Toledo, Toledo, 1889.

Gonzá1.ez Herrero, Manuel: Nolas bistórico-juridicas sobre los gremios.

Gonzaro Soto, Julio: Las estructuras corporativas gremiales (Discurso de ingreso), Institución Fernán González, Burgos, 1963.

Guillo't Carratalá, José: Los gremios artesanos españoles, 2." ed., Madrid, 1959.

Heredia Moreno, María del Carmen: Estudio de los contratos de aprendizajc artístico en Sevilla a comienzos del siglo XVIII, Diputación Provincial de Sevilla, Sevilla, 1974.

Ibarra y Folgado, José María: Los gremios del metal en Valencia (Tesis doctoral), Facultad de Filosofía y Letras, Sección de Historia, 1919.

Izarra Retana, Jesús de: Vecindades, cofradías y gremios, Vitoria, 1940.

Jiménez de Gregorio, Fernando: Toledo a mediados del siglo XVII, economía, sociedad y administración (Discurso de su recepción académica), Real Academia de Bellas Artes y Ciencias Históricas de Toledo, Toledo, 1959.

JimÉNEZ DE Gregorio, Fernando: Incidentes en algunos gremios y cofradias de Murcia a finales del siglo XVIII, Universidad de Murcia.

JoRdín de Asso y del Río, Ignacio: Historia de la economía politica de Aragón, C. S. I. C., Zaragoza, 1947 (el libro, en su primera cdición, data de 1798).

Jorge Aragoneses, Manuel: Contribución al inventario provincial de artes industriales, en «Monteagudo», núm. 25 (1959).

Konetzke, Richard: Las ordenanzas de gremios como documentos para la bistoria social de Hispanoamérica durante la época colonial, en Estudios de bisloria social de España. Instituto Balmes de Sociología (C. S. I. C.), Madrid, 1949, págs. 441-524.

Larruga y Boneta, Eugenio: Historia de la Real y General Junta de 
Comercio, Moneda y Minas (Colección íntegra de los reales decretos, pragmáticas, resoluciones, órdenes y reglamentos), Madrid, 1789.

López de Ayala y Alvarez de Tolrdo, Jerónimo (Conde de Cedillo):

Toledo en el siglo XVI después del vencimiento de las comunidades (Discurso de ingreso en la Real Academia de la Historia), Madrid, 1901.

Lozoya (Marqués de): Los gremios españoles, Escuela Social de Madrid (Ministerio de Trabajo), Madrid, 1944.

Marina Muñoz, Juan: La calle de las armas, en «La Ilustración Ibérica», núm. 272 (Barcelona, 17 de marzo de 1888).

Martínez y González, Santiago: Los gremios (Conferencia), SalamanCa, 1899.

Martínez del Peral Fortón, Rafael: La navaja española antigua, Instituto de Estudios sobre Armas Antiguas (C. S. I. C.), Madrid, 1979.

Martínez del Peral Fortón, Rafael: Ciento catorce punzones de navaja, Ed. Almarabú, Madrid, 1985.

Matilla Tascón, Antonio: El primer catastro de la villa de Madrid, en «Revista de Archivos, Bibliotecas y Museos», tomo LXIV, vol. 2 (1961), págs. 464-529.

Matilla Tascón, Antonio: La inica contribución y el calastro de la Ensenada, Madrid, 1947.

Molas Ribalta, Pedro: Los gremios barceloneses del siglo XVIII, Confederación Española de Cajas de Ahorros, Madrid, 1970.

Moreno Navarro, Isidoro: Las hermandades andaluzas. Una aproximación desde la uniropología, Publicaciones de la Universidad de Sevilla, Sevilla, 1974.

Palacio, Ramón Miguel: Discurso económico-político en defensa del trabajo mecánico de los menestrales y de la influencia de sus gremios en las costumbres populares, conservación de las artes y bonor de los artescinos, Madrid, 1778.

Pedraza, Esperanza: Espaderos toledanos, en Fábrica Nacional de Armas de Toledo, Fábrica Nacional de Armas, Toledo, 1982, págs. 157-176.

Pérez Bueno, Luis: Indice de oficios artesanos, Obra Sindical de Artesanía (Delegación Nacional de Sindicatos), Madrid, 1950.

Planes Albe'ts, Ramón: L'activitat industrial a Solsona durant el segle XVIII. Una primera aproximació, en «Cardener», núm. 1 (separata), Institut d'Estudis Locals de Cardona (diciembre 1983).

Quetglas Gaya, Bartolomé: Los gremios de Mallorca, Palma de Mallorca, 1939.

Redondo Veintemillas, Guillermo: Las corporaciones de artesanos de Zaragoza en el siglo XVII (Tesis), Institución Fernando el Católico, Zaragoza, 1982. 
Regla Campistol, Juan: Hisloria general del trabajo. La época del artesanado. Apéndice: La época del antesanado en Éspaña (siglos V$X V I I I)$, tomo II, Ed. Grijalbo, Barcelona, 1965, pág. 435.

Rico y Sinobas, Manuel: Noticia histórica de la cucbillería y de los cuchilleros antiguos cn España, en «Almanaque del Museo de la Industrial» (Madrid, 187.1).

Rico y Sinobas, Manuel: La cacbillería en España (siglo XVII), en «Historia y Arte», tomo 1 (marzo de 1885 a febrero de 1896), Hauser y Menet, Editores, pág. 6.

Roma y Rosell, Francisco: Disertación bistórico-político-legal por los colegios y gremios de la ciudad de Barcelona y sus privativas, Barcelona, 1766 .

Rumeu dF. Armas, Antonio: Hisloria de la previsión social en España. Cofradias, gremios, bermandades y montepios, Ed. Revista de Derecho Privado, Madrid, 1944.

San Román y Fernández, Francisco de Borja: Los gremios toledanos en el siglo XVII, Publicaciones de la Delegación Provincial de Educación Nacional de F. E. T. y de las J. O. N. S., Toledo, 1970.

Sancho Seral, Martín Luis: El gremio zaragozano del siglo XVI. Dalos para la bistoria de la organización corporativa del trabajo en España (Tesis), Ed. Tipografía la Academia, Zaragoza, 1925.

Santingo Palomares, Francisco: Noticia de la Fábrica de Espadas de Toledo... Toledo, 1772.

SEgarra, Estanislao: Los gremios, Barcelona, 1911.

Torrella Niubó, Francisco: Gremios y cofradias, Cámara Oficial de Comercio e Industria, Tarrasa, 1961.

Tramoyeres Blasco, Luis: Instituciones gremiales, su origen y organizución en Valencia, Ayuntamiento de Valencia, 1889.

UÑ y SARThou, Juan: Las asociaciones obreras en España, Madrid, 1900.

Villas Tinoco, Siro: Los gremios malagueños (1700-1746), 2 vols. (Tesis doctoral), Universidad de Málaga, Málaga, 1982.

Viñas y Mey, Carmelo: Cuadro económico-social de la España de $1627-$ 1628. Pragmática sobre lasas de las mercaderías y mantenimientos, jornales y salarios, en «Anuario de Historia Económico-Social», año I, núm. 1 (enero-diciembre 1968), Seminario de Historia Social y Económica, Facultad de Filosofía y Letras de la Universidad de Madrid. 


\section{A PENDICE}

\section{ORDENANZAS DEL GREMIO DE CUCHILLEROS DE BARCELONA DE 12 DE MAYO DE 1512}

Que se elijan todos los años tres Prohombres para el régimen del gremio; que estos tengan facultad por sí de juntar los vocales siempre que lo juzguen conveniente; que no puedan resolver de su propia autoridad caso alguno árduo ó extraordinario, y sí sólo los comunes, según la práctica del gremio, y el tenor de sus ordenanzas.

Que los que hayan sido una vez Prohombres ú oficiales del gremio no pueden volver á obtener cargo alguno sin haber mediado dos años.

Que cada individuo pague anualmente quatro sueldos y quatro dineros que se han de exigir por semanas para los gastos de la fiesta del Santo tutelar.

Que ningún maestro pueda prestar su nombre á otro só pena de veinte y cinco ducados.

Que para la buena harmonía de los gremiales, y perfección del oficio, en la casá de las juntas se guarde un libro en que estén estampadas las marcas con que cada individuo señala las piezas de su fábrica.

Que a fin de cvitar la proporción con que los demás fabricantes de fuera de Barcelona podían introducir fraudulentamente en ella artefactos con marcas contrahechas, se rompan aquellos que se encuentren con semejantes engaños.

Que para que el público y el extrangero queden bien servidos en el surtimiento de piezas de fábrica barcelonesa, debían los maestros traher toda la obra concluída á la casa del gremio para ser allí examinada antes de poderla vender, con la ley de que no hallándose de buena calidad se rompa á presencia de los Prohombres.

Que los aspirantes á la maestría debían haber hecho quatro años de aprendizage, y dos de oficialía en casa de maestro aprobado con obrador propio y corriente, sujetándose á pagar por la recepción veinte y quatro ducados.

ORDENANZAS DEL GREMIO DE CUCHILLEROS DE SEVILLA DE 6 DE SEPTIEMBRE DE 1525 RECOPILADAS EN 1632

Por quanto en el oficio y arte de cuchillería, fasta agora no ha auido ordenanças, por do los maestros y oficiales del dicho oficio touiessen orden en razon del vso, y exercicio del dicho oficio, de cuya causa, se han fecho, y haze puñales, y cuchillos, y otras obras falsas, y defectuosas con 
atreuimiento: y por lo assi fazer, no ay ordenanças por do sean punidos, y castigados, y dello resulta otros muchos incouenientos en gran daño, y agrauio del bien, y pro comun desta muy noble, y muy leal cibdad de Seuilla, y vezinos, y moradores della, siendo, como es el dicho oficio de cochilleria, vno de los principales oficios y arte, que ay en la dicha cibdad, queriendo en ello proueer, como es justo. Nos los fieles executores desta muy noble y muy leal cibdad de Seuilla, y de toda su tierra, por la Reyna nuestra señora, con acuerdo del honrado Francisco de Riaño Teniente de Fiel executor en la dicha cibdad, por el muy magnifico señor Don Yñigo de Velasco, Assistente de la dicha cibdad por sus Altezas; que de oy en adelante todos los maestros y oficiales del arte y oficio de la cuchilleria desta cibdad y su tierra, y a las otras personas, a quien lo de yuso contenido se dirige o dirigir pueda, que cumplan, y obseruen los capitulos y ordenanças siguientes: so las penas en ellas contenidas.

Primeramente ordenamos y mandamos, que todos los maestros y oficiales del dicho oficio, el dia de señor Sant Iuan Baptista, de cada vn año, se ayunten en su hospital, o en otro lugar que para ello señalen: y de vna vnion y conformidad, elijan entre si dos personas de los mass sabidores y expertos en la dicha arte, y de mejor conciencia, que en el dicho oficio aya, para que estas dichas dos personas sean, el vno Alcalde, el otro veedor del dicho oficio el año, porque assi los eligieren: y después de assi nombrados, y elegidos, y confirmados, otro dia siguiente los traygan antel Cabildo a presentar, para que dellos resciban la solemnidad y juramento que en tal caso se requiere, antes que vsen del dicho oficio, so pena de dos mill marauedis.

Otrosi, ordenamos, y mandamos, que ninguna persona pueda vsar ni vse del dicho oficio de oy en adelante, ni de poner ni de assentar tienda, sin que primeramente sea examinado por los dichos veedores, juntamente con otros dos maestros, que para ello con juramento escogieren: y despues assi juntados, examinado, lo traygan y presenten ante Nos, y Nos le confirmaremos en el dicho oficio, y le mandaremos dar nuestro mandamiento para el vso y exercicio del dicho su oficio: so pena que el que de otra manera pusiere tienda, pierda la obra que assi fiziere y tuuiere, y mas pague de pena seyscientos marauedis: y que el tal hombre que se ouiere de examinar pague a cada vno de los dichos examinadores por su trabajo, vn real de plata.

Otrosi, ordenamos y mandamos, que todas las obras que de aqui adelante se fizieren, vayan bien, y perfectamente fechas y acabadas, sinque lleuen repelas, ni otro daño alguno encubierto: y que sean calçadas de tales obras de buen azero según su razón de cada vna de las dichas obras: en las quales los dichos maestros oficiales pongan sus señales, porque sean conoscidas quien las fizo: so pena, que si en algo de lo contrario del dicho 
capitulo excedieren, que incurran en la pena de los dichos seyscientos marauedis, y pierda la obra que le fallaren, y ouiere vendido por la primera vez: y por la segunda la pena doblada: y por la tercera incurra en las dichas penas, y no vse mas del oficio en esta cibdad y su tierra.

Otrosi, ordenamos, y mandamos, que no aya regatoneria de las obras tocantes al dicho oficio de cuchilleria: so pena de seyscientos marauedis, y perdida la obra que assi compraren para tornar a reuender, o reuendieren, por la primera vez: y por la segunda la pena doblada, y esté en la carcel nueue dias: y por la tercera incurra en las dichas penas; y no vse mas del dicho oficio.

Otrosi, ordenamos, y mandamos, que si algun maestro, o oficial del dicho oficio coprare azero, o fierro, o otra obra qualquiera, tocante al dicho oficio de vn quintal arriba, assi en la dicha cibdad, como fuera della, dentro del termino de las cinco leguas que den parte a los otros oficiales del dicho oficio, rata por rata, lo que a cada vno dellos cupiere, por el tanto, quanto le ouiere costado: pagando las costas que les cupieren y esto se entienda, pidiendo los oficiales el tal azero, o fierro a tercero dia entiendase el tercero dia, dende que viene a su noticia, so la dicha pena de seyscientos marauedis.

Otrosi, ordenamos, y mandamos, que los dichos veedores con mucha diligencia caten, y examinen las dichas tiendas, y las obras tocantes al dicho oficio de cuchilleria, que fallaren en las tiendas de los dichos maestros oficiales del dicho oficio y otras quales quier personas que las tuuieren para vender, o tuuieren colgadas, o puestas en las dichas sus casas y tiendas las vezes todas que quissicren y fueren justo especialmente, que alomenos caten las dichas casas y tiendas, y examinen las dichas obras doze vezes en el mes, y las obras que fallaren excessiuas, y contra la forma y tenor destas dichas ordenanças, las saquen de poder, o poderes de quien las fallaren, y las traygan ante Nos en el mesmo dia, porque Nos fagamos en el caso lo que sea justicia. $\mathrm{E}$ assi mismo mandamos, a todos los oficiales y otras qualesquier personas en cuyo poder fallaren las dichas obras para vender, que cada y quando que los veedores, o alguno dellos les fuere a ver sus obras, fagan sus casas llanas, y sin ningun temor les dexen catar todas las obras de la cuchillería so pena de dos mill marauedis y nueue dias en la carcel.

Otrosi, ordenamos y mandamos, que qualquier cuchillero que guarneciere puñal a qualquier regaton, ni a otra persona que lo quisiere para vender, sino fuere cuchillero, que pague seyscientos marauedis de pena, las dos partes, para reparos desta cibdad y la otra parte, para quien lo denunciare.

Las quales penas pecuniarias aplicamos, las dos tercias partes para los propios desta cibdad, y la vna al denunciador. 
Otrosi, por quanto en estas ordenanças no defienden, que ningun oficial que no sea del oficio de cuchilleros no pueda tener obrero en su tienda del oficio de cuchilleria: lo qual dizque algunos oficiales especialmente vayneros, y otras personas agenas del dicho oficio tienen los tales obreros, y fazen obras en sus casas, diziendo, que lo pueden fazer y porque si esto ouiesse de passar, recibirian mucho daño los maestros cuchilleros, y perjuyzio los que las tales obras compran. Y queriendo en ello proueer, ordenamos, y mandamos, que de oy en adelante ninguna persona que no fuere maestro examinado del dicho oficio de cuchilleria, ni pueda tener obrero ninguno que labre en su casa: so pena, que el que lo contrario fiziere, por la primera vez el que tal obrero tuuiere en su casa, pague seyscientos marauedis; y por la segunda la dicha pena, y tres dias en la carcel; y por la tercera, la pena doblada, y sea traydo a la verguença publicamente: el dicho obrero que supiere la ordenança, y no la guardare, aya las dichas penas.

Otrosi, porque en estas ordenanças no esta puesto vn capitulo que conuiene para que los dichos cuchilleros viuan en paz, en razon de los aprentizes que tienen, y resciben para les mostrar el dicho oficio. Otrosi, ordenamos, y mandamos, que de aqui adelante, ningun maestro ni otra persona alguna, no sossaque ningun moço, ni aprenliz, que otro oficial tenga, por contrato o por aueriguacion: saluo si el dicho aprentiz estuuiere despedido de su amo, no auiendo passado el dicho contrato, o aueriguacion entrellos; que en tal caso el tal aprentiz pueda estar con quien quisiere: so pena, que el que sossacare el dicho aprentiz de la manera susodicha, pague de pena seyscientos marauedis, y no pueda tener el dicho aprentiz; y torne el dicho aprentiz a seruir al primero amo, conforme al contrato, o aueriguacion: de la qual dicha pena de marauedis, aplicamos las dos tercias partes, para los propios de Seuilla; y la vna al denunciador. Andres de Robles. Christoual Pinelo. Diego de los Rios. Francisco de Melgarejo.

En este oficio de cuchillero no ha de auer Alcaldes, porque en quanto a este sc revoco por el Cabildo, y Regimiento de Scuilla, en scys dias del mes de Setiembre de mill y quinientos y veynte y cinco años.

\section{ORDENANZAS DEL GREMIO DE CUCHILLEROS DE SOLSONA DE 1770}

Primeramente estatuyen y ordenan que cualquier persona que querrá ser maestro del officio de daguero de la presente ciudad y cofradía, aya y deva avel practicado por aprendiz con maestro del mismo officio de da- 
guero de la presente ciudad o fuera de ella por el espacio de cuatro años y llevar certificación jurada del maestro con quien habrá practicado del mismo officio en los mencionados quatro años.

Otrosí, estatuyen y ordenan que por el examen de dicho officio de daguero y admitirla a él, deva el gremio de dagueros de dicha ciudad y cofradía elegir y deputar dos maestros del officio de daguero de la misma ciudad y cofradía por examinadores de la persona que pidiere el lugar u plaza para maestro daguero, los quales examinadores harán fabricar a la tal persona unas tigeras de tendero de paños, un cortaplumas, dos cochillos de mesa a la inglesa, haziendo los puños, vulgarmente nombrados ab dolsas, aviendo de asistir los referidos examinadores quando y en la ocasión se fabricarán u trabajarán dichas cosas, pagados y satisfechos de su condecente salario por la tal persona querrá ser examinada. Tasador dicho salario por los priores de dicha cofradía que en dicha ocasión fueren.

Otrosí, estatuyen y ordenan que todos los hijos de qualquier maestro daguero de la presente ciudad y colradía querrán ser examinados por ser maestros dagueros de la misma ciudad y cofradía, los examinadores que para dicho examen serán elegidos y nombrados solamente les harán fabricar a los tales hijos un cortaplumas u otras piexas a aquellos bien vistas; a excepción, empcro, del hijo primogénito de los tales maestios, que únicamente le harán o deverán hazer fabricar un cortaplumas, aviendo de obscrvar lo micno que está prevenido en el capítulo o ordenanza immediata antecedente.

RFLACION DE LOS CUCHILLEROS

MENCIONADOS EN EL REGISTRO GENERAL DEL SELLO

DEL ARCHIVO GENERAL DE SIMANCAS EN TIEMPO

DE LOS REYES CATOLICOS

4 noviembre 1476 Perdón a Diego García, cuchillero, vecino de Ecija, culpable de la muerte de Alfonso Prieto, certajero, vecino de Córdoba.

8 septiembre 1477 Perdón de Viernes Santo a Diego de Mendoza, vecino de Toledo, acusado de la muerte de Juan Abad, cuchillero.

3 noviembre 1477 Carta de los justicias de Jerez de la Frontera, a petición de Martín Rodríguez, cuchillero, vecino de dicha ciudad, ordenándoles que, si la sentencia dada contra Juan Bernal de Avila y Alfonso 
12 diciembre 1478

18 febrero 1480

27 junio 1489

25 junio 1490

14 julio 1490

13 septiembre 1490

... febreto 1491

25 octubre 1494
Díaz de Villacreces es pasada en cosa juzgada, la ejecuten.

Que vean una sentencia a petición de Alfonso Rodríguez, cuchillero, vecino de Córdoba, hijo de Diego Alfonso, en que fue dado por libre e quito de una acusación e se la guarden.

Provisión a petición de Rodrigo Alonso, cuchillero, vecino de Ciudad Real, en amparo de una sentencia que revocaba otra anterior dada contra él en el pleito seguido con el comendador Alvaro Gaitán, vecino también de Ciudad Real. Provisión, a petición de Catalina Fernández, mujer que fue de Diego Fernández, cuchillero, ya difunto, dándola por libre y quita de la deuda que el dicho su marido tenía con Diego de Tordesillas por cierto cobre que de él tomó fiado. Para que no pueda renunciar la cadena Juan Rodríguez de Perogozo, cuchillero, vecino de Castro del Río (Córdoba).

Comisión, a petición de Isabel Martínez, sobre los agravios que ella y su hija han recibido de García Rodríguez, cuchillero, vecino de Sevilla.

Carta ordenando se pague a Juan de Córdoba, cuchillero, vecino de Sevilla, 7.000 maravedís, importe que pagó por una esclava de La Gomera, y que le ha sido tomada por orden de Sus Altezas, ya que los vecinos de esta isla, como cristianos, son libres.

Emplazamiento a Abrahen Huesque, judío, a petición de Fernando González, cuchillero, vecino de Badajoz, que apelaba de una sentencia que cita, dada por el bachiller Alfón de la Fuente, corregidor de dicha ciudad; por cste motivo sc remite este negocio a la Chancillería.

Para que el maestrescuela del Estudio y Universidad de Salamanca y su lugarteniente, y el doctor Ponce de Madrigal, viceescolástico del citado Estudio, no intervengan en las demandas puestas contra los moros, vecinos de Madrid: Diego, cuchillero; Mahoma, calderero; Hamad Robledo y maestre Alí, cuchillero, contra los cuales se dieron ciertas cartas. 
Fernand González, cuchillero, vecino de Llerena (Badajoz), apela de una sentencia pronunciada por el juez de bienes confiscados en el obispado de Badajoz y maestrazgo de Santiago a favor de Diego Caballero, vecino de la citada villa de Llerena, sobre unas casas que había comprado a Diego de Arreo, recaudador de los bienes de la Inquisición.

ESCRITURA DE APRENDIZ DE CUCHILLERO

Marzo 9

Sepais como yo Antonio Portilla vecino de esta villa de Albacete, curador de Alonso Vazquez menor mi sobrino hijo de Alonso Vazquez y de Maria Idem difuntos vecinos que fueron de esta dicha villa otorgo que pongo para aprender del oficio de cuchillero al dicho Alonso Vazquez menor mi sobrino con Domingo Zebrian Maestro del dicho oficio vezino de esta dicha villa por tiempo $i$ espacio de cinco años que se quentan desde oi dia de la fecha asta ser cumplidos en los quales le a de enseñar todo lo a el tocante sin ocultarle cosa alguna i le ha de dar de comer beber i calzar vida honesta rrazonable $\mathrm{i}$ al fin de dichos cinco años le ha de dar asimismo un bestido entero nuebo como sea costumbre en esta tierra, i por esta rrazon le tengo de dar a dicho maestro dozientos reales de vellon por una vez los quales pagare por el dia y fiesta de nuestra señora de septiembre de este presente año a que me obligo en forma y con titulo derechos con renunziazion de las leyes de tal entrega, dolo, engaño i demas del caso como en ellas se contiene $=$

$\mathrm{Y}$ asimismo me obligo a que el dicho mi sobrino cumplira el dicho tiempo y asistira a dicho ofício en la casa $i$ tienda de dicho maestro i sise ausentare lo traere a mi costa i cumplira quales quiera fallas y dias que aia dejado de travajar por dicha ausencia enfermedad o otra razon y si asi no lo hiziere le pagare los daños e intereses que se siguieren al dicho Domingo Zebrian con las costas e gastos que se le ocasionaren $=$

$\mathrm{Y}$ estando presente a todo lo referido yo el dicho Domingo Zebrian azepto esta sentencia en todo y por todo y recivo por aprendiz del dicho mi oficio a el dicho Alonso Vazquez por el dicho tiempo de cinco años en los quales me obligo a enseñarle todo lo a el tocante y perteneziente en la forma que como tal maestro de dicho oficio lo deuo hazer y executar sin ocultarle cosa alguna. Y por el dicho tiempo me obligo asimismo 
a darle de comer vestir y calzar, vida honesta rrazonable, y al fin de dichos cinco años le darey tambien vn bestido entero nuebo como se acostumbra, y de todo ello me constituio deudor y doy por entregado a mi voluntad con renunziazion de las leyes de la entrega i demas del caso como en ellas se contiene $=$

$Y$ si por tratarle mal o por otra causa en que yo tenga culpa o malizia sc auscntare y fucre de mi casa al dicho aprendiz no he de tener aczion a prezisarle a que buelba y si se me hubiesen pagado los dichos dozientos reales los he de rrestituir al susodicho y pagarle los daños e yntereses que se le siguieren de que tambien me constituio deudor con la misma renunziazion $=$

Y para que cada uno por lo que nos toca cumpliremos esta escritura, obligamos nuestras personas y vienes auidos y por auer i damos poder a las justicias de su magestad de quales quier causas que sean para que nos apromien como por sentencia pasada en cosa juzgada y renunziamos las leies de nuestro fauor y ageno y en forma y lo otorgamos en la villa de Albacete a nuebe dias del mes de marzo de mill y setezientos años siendo testigos Nicolas de Arias Julian Romero y Francisco de Orea Zercadillos todos de Balencia y los otorgadores a quienes yo el escribano doy fe e conozco firmo el que supo escribir y por el que no vn testigo

Domingo Zebrian

Por los dos reales doi fee

Francisco de Orea Zeicalilios

Orea

Antes my

Antonio de Orea 


\title{
* \\ NOM I N A
}

De los ultimos, y mas famofos ARMEROS DE TOLEDO, que labraron Effpadas hafta la entrada del prefente Siglo XVIII. en que acabó esfa Fábrica.

Ván por Alphabéto, por no faberfe de cierto el tiempo en que algunos de ellos florecieron.

\author{
por \\ FRANCISCO SANTIAGO PALOMARES
}

Alonfo de Sahagun, el viejo, vivia año de 1570.

Alonfo de Sahagun, el mozo.

Alonfo Perez.

Alonfo de los Rios. Labró tambien en Cordova.

Alonfo de Caba.

Andrés Martinez, bijo de Zabála.

Andrés Herraez. Labró tambien en Cuenca.

Andrés Muneften. Labró tambien cn Calatayud.

Andrés Garcia.

Antonio de Baena.

Anton Gutierrez.

Antonio Gutierrez.

Antonio Ruiz. Labró tambien en Madrid. Uso afsimifmo la $\mathrm{Ci}$ tra de fu Nombre.

Adrian de Zafra. Labró tambien en San Clemente.

Bartholomé de Nieva.

Cacaldo, y el Campanero, Compañeros. Labráron en Cuellar, y Badajoz.

Domingo de Orozco.

Domingo Maeftre, el viejo.

Domingo Maeftre, el mozo.
Domingo Rodriguez.

Domingo Sanchez, llamado comunmente: El Tixerero.

Domingo de Aguirre, bijo de Hortuño.

Domingo de Lama.

Dionyfio Corrientes. Labró tambien en Madrid.

Fabian de Zafra, bijo de Adrian. Francifco Ruiz, el viejo.

Francifco Ruiz, el mozo, fu bijo, bermano de Antonio.

Francifco Gomez.

Francifco de Zamora. Labró tambien en Sevilla.

Francifco de Alcozer. Labró tambien en Madrid.

Francifco Lurdi.

Francifco Cordui.

Francifco Perez.

Giraldo Reliz.

Gonzalo Simón.

Gabriel Martinez, bijo de Zabála.

Gil de Almaú.

Hortuño de Aguirre, el viejo.

Juan Martin.

Juan de Leyzalde. Labró tambien en Sevilla. 
Juan Martinez, el viejo.

Juan Martinez, el mozo. Labró también en Sevilla.

Juan de Almau.

Juan de Toro, bijo de Pedro de Toro.

Juan Ruiz.

Juan Martinez de Garata, Zabála, el viejo.

Juan Martinez Menchaca. Labró también en Lisboa.

Juan Ros.

Juan Moreno.

Juan de Salcedo. Labró tambicn en Valladolid.

Juan de Meladocia.

Juan de Vargas.

Juanes de la Horta. Vivia el año 1545.

Juanes de Tolledo.

Juanes de Alquiniva.

Juanes Muleto.

Juanes, el viejo.

Juanes de Uriza.

Julian del Rey. Labró tambien en Zaragoza, y usó otras Marcas.

Julian Garcia. Labró tambien en Cuenca.

Julian de Zamora.

Jofeph Gomcz, bijo de Francifco Gomez.

Jufepe de la Hera, el viejo.

Jufepe de la Hera, el mozo.

Jufepe de la Hera, el Nieto.

Jufepe de la Hera, el Vifnieto.

Jufepe del Haza, bijo de Silveftre Nieto.

Ignacio Fernandez, el viejo. Ignacio Fernandez, el mozo.
Luis de Nieves.

Luis de Ayala, bijo de Tbomás de Ayala.

Luis de Velmonte, bijo de Pedro de Velmonte.

Luis de Sahagun, bijo de Alonfo el viejo.

Luis de Sahagun, llamado Sabaguncillo, bijo de Alonfo el viejo.

Luis de Nieva. Labró tambien en Calatayud.

Lopus Aguado, bijo de Juanes Muleto. Labró tambien en San Clemente.

Miguel Cantero.

Miguel Sanchez, bijo de Doiningo.

Melchor Suarez. Labró tambien en Lisboa.

Nicolás Hortuño de Aguirle, nieto de Hortuño, 1637.

Pedro de Toro.

Pedro del Arechiga.

Pedro Lopez. Labró tambien en Orgaz.

Pedro de Lezama. Labró tambien en Sevilla.

Pedro de Lagaretea. Labró tambien en Bilbao.

Pedro de Orozco.

Pedro de Velmonte.

Roque Hernandez.

Sebaftian Hernandez, el viejo. $V i$ via 1637.

Sebaftian Hernandez, el mozo. Labró tambien en Sevilla.

Silveftre Nieto.

Silveftre Nieto.

Thomás de Ayala. 1625.

Zamorano, el Toledano. 